\title{
Monografias da Revista do Serviço Público
}

A Técnica da Comunicação na Redação Oticial, um dos trabalhos premiados e recomendados para publicação pela Comissão Julgadora do Concurso de Monografias, realizado pela REVISTA DO SERVIÇO PÚBLICO, em 1970 , demonstra a necessidade da modernização dos métodos de redação tradicionalmente utilizados nas repartições públicas.

É uma monografia cativante pela critica bem humorada que faz à línguagiosa, emperrada e falsamente cerimoministrusada na correspondência aduma linga, propugnando "em favor de Vios linguagem oficial despida de atatam e circunlóquios que se manifesadjetiv fórmulas ditas de cortesia, na redundação supérflua, nas perifrases ciosismos, nas metáforas, nos prefim: em to em tudo o que torna o pensameninterpretaco dificulta a informação, a dige".

\footnotetext{
A prosa "cheia de ornatos, de anatrapõe, de excessivo vocabulário" cona correspondenibilidade de vincular-se $d_{\theta}$ qualquenência oficial ao dinamismo qualquer veículo moderno de Comu-
}

nicação - o jornal, o rádio, a TV -, sentindo que "na linguagem dos documentos públicos, muito do que se escreve constitui obstáculos à Comunicação. Obstáculos que, se removidos, somente virão favorecer a tarefa dos que administram". E sugere a revisão dos textos de redação oficial, tendo em vista a maior clareza do tema, e a renovação estrutural dos documentos, "à luz das técnicas modernas da Comunicação, sem prejuizo do conteúdo informativo".

Tendo concorrido sob o pseudônimo de Pero Vaz de Caminha, o autor, José Augusto Guerra, é professor da Universidade de Brasilia (UNB) e do Centro Universitário de Brasília (CEUB); bacharelou-se pela antiga Faculdade de Direito do Rio de Janeiro; exerce o jornalismo, profissionalmente, desde 1944 , sendo especializado na crônica parlamentar; funcionário da Câmara dos Deputados, por concurso público, desde 1951, preparou para a Diretoria de Documentação e Publicidade 20 Volumes da Coleção Documentos Parlamentares; lançou a publicação Resenha Legis/ativa, editada pela SecretariaGeral da Presidência; chefiou o Ga- 
binete do Deputado José Bonifácio, quando Presidente da Câmara; tem participado das bancas examinadoras dos concursos públicos do Legislativo; é autor de vários ensaios sobre Literatura, Sociologia e Comunicação; nasceu em Maceió, Es̀tado de Alagoas, e reside em Brasilia, Distrito Federal.

A Comissão Julgadora do Concurso de Monografias da REVISTA DO SERVIÇO PÚBLICO de 1970 foi composta pelos seguintes membros: Coronel Octávio Costa, Chefe da Assessoria Especial de Relações Públicas da Pre- sidência da República; Dr. Antônio Fonseca Pimentel, então Subchefe do Gabinete Civil da Presidência da República; Prof. Edson Nery da Fonseca, da Universidade de Brasília; Prof. Paulo Vieira da Silva, da Universidade de Brasilia; Dr. Corsíndio Monteiro da Silva, Assistente Jurídico do DASP; Prof. Henrique Teixeira Tamm, então Coordenador do Ensino Médio da Secretaria de Educação do Governo do Distrito Federal; e Prof. Araújo Cavalcanti, Diretor da REVISTA DO SERVIÇO PÚBLICO. (AV). 


\title{
A Técnica da Comunicação na Redação Oficial
}

\author{
A memória de meu pai \\ e a minha mãe
}

\section{José Augusto Guerra}

SUMARIO: I - INTRODUÇÃO; II - DESENVOLVIMENTO; 1. A Procura da Expressão Escrita; 2. Técnicas da Comunicação na Redação Oficial; 3. Reformas e Tentativas; 4 . Redação e Psicologia Social; III - CONCLUSÕES; IV - SUGESTÕES PRÁTICAS; V - REFERENCIAS BIBLIOGRÁFICAS.

Quando minutamos um ofício ou abrimos um telegrama năo nos lembramos de que vai distante o tempo em que, na ausência da escrita, o que valia era a memória. E porque só na memória se podia confiar (como estavam os antigos tăo próximos da técnica do computador e dos métodos audiovisuais) a arte de ensinar e de aprender obedecia quase a um ritual. No lugar da autoridade do texto imPresso, que hoje citamos como testemunhas do que estamos afirmando, confiava-se na autoridade da "palavra Viva e perdurável", aquela que se transmitia de geração a geração. Pelas dificuldades de acesso aos segredos da escrita, procurava-se memorizar. Era uma pedagogia diferente e de resultados tão precisos que hoje admira terem chegado até nós narrativas que se mantiveram intactas, durante séculos, até se transformarem em símbolos gráficos.

Porque se devia saber de cor as lições dos mestres, recorria-se à mnemotécnica e à dança, a fim de facilitar o aprendizado. Os requisitos estilísticos utilizados visavam também a uma mais fácil memorização. Só assim compreendemos o porquê de tantas repetições, antíteses, metáforas, gradações e parábolas nas narrativas evangélicas, nos textos de Buda, no Corão e no Talmude. Em verdade, em verdade vos digo... Não julgueis para não serdes julgados... Porque quem pede recebe, quem busca acha, e a quem bate se abre... E a memória guardava e transmitia essas apóstrofes, os discursos inteiros, 
as histórias; memória de discípulos habituados a ouvir, a guardar e a repetir. "Um bom discípulo é semelhante a uma cisterna bem construída, donde não foge nem uma gota de água" lembra Daniel-Rops, citando antiga definição de rabis judaicos (1).

\section{$-00000-$}

Quando cogitamos de escrever sobre a redação oficial, não tencionávamos descer à raiz do tempo, para compreender a relação entre pensar e falar, falar e escrever, tendo em vista a Comunicação. Se sabemos pensar, o raciocínio se desenvolve de tal maneira, que tudo o que falarmos ou escrevermos será compreendido. O contrário acontece: ninguém nos entenderá se nem mesmo nós estamos certos do que vamos dizer.

$\mathrm{Na}$ correspondência epistolar, entretanto, nem sempre o saber pensar resulta na expressão direta e objetiva. As estruturas, de rigorosas, podem dificultar nossa capacidade de expressão. $E$, dificultando o que desejamos dizer, as nossas melhores intenções de clareza e simplicidade caem porr terra.

Voltemos aos textos antigos. Porque eram para ser memorizados, são despojados de redundâncias. Salvo nas metáforas mais simbólicas, nas descrições de sonhos, haja vista o Apocalipse e os livros dos Profetas, as narrativas eram as mais simples possiveis. Adjetivação escassa, quando não inexistente. Uso freqüente da coordenação, em lugar da subordinação: pro- curava-se seguir a tradição oral. Rememore-se a Oração Dominical: não se encontra um só adjetivo no Pai Nosso...

Colocada em segundo plano a memória, depois que passamos a confiar nossos conhecimentos à escrita, começamos a dar cordas à imaginação e a criar e recriar maneiras de dizer. Abandonamos o estilo antitético e nos enveredamos nas perifrases. $E$ houve época em que a mais louvada arte de escrever estava na maior dificuldade de expressar.

A correspondência oficial não ficaria imune de uma prosa cheia de ornatos, de analogias, de excessivo vocabulário, a pretexto de cortesia. $\mathrm{CO}^{-}$ mo as transformações no mundo burocrático se fazem mais lentas, e dependem irremediavelmente de portarias, grupos de trabalho, estudos e planos, ainda hoje escrevemos e nos comunicamos, os funcionários públicos, com as mesmas fórmulas de uma época em que havia serenatas e lia-se $A$ Moreninha.

Entretanto, se considerarmos que a correspondência oficial tem possibilidades de vincular-se ao dinamismo de qualquer veículo moderno de Comunicação - $\circ$ jornal, o rádio, a TV sentimos que, na linguagem dos documentos públicos, muito do que se escreve constitui obstácuios à Comunicação. Obstáculos que, se removidos, somente virão favorecer a tarefa dos que administram. 


\section{II - DESENVOLVIMENTO}

\section{1. À PROCURA DA EXPRESSÃO ESCRITA}

Quando o chefe de gabinete do Ministro chama a sua secretária e lhe transmite instruções sobre a correspondência que deve ficar pronta até o final do expediente, não percebe que esta sua rotina é das mais antigas no mundo da Comunicação. Embora a secretária há quinze anos venha rabiscando numa taquigrafia particular, de uso próprio, as recomendações de tantos chefes de gabinete quantos os ministros, Jamais se preocupou com a importância de sua missão. Ambos, o chefe de gabinete e sua secretária, tão habituados se encontram à rotina, que preparar a correspondência ministerial é mais uma atividade comum, corriqueira, ronceira até, que um ato de Criação epistolar. Claro que a equipe do gabinete é um punhado de funcionários, entre os melhores, hábeis datilógrafos. E quando o Sr. Ministro assina dezenas de ofícios, cujo papel especial traz o timbre da República, em certas ocasiōes faz breves comentários elogiando "o belo trabalho do Gabinete", com a sensibilidade de quem, conhecedor da psicologia humana à Dale Carnegie, sabe que um comentário positivo é um estimulante dos mais saudáveis; e sabe ainda que, naquela mesma tarde, seu chefe de gabinete transmitirá à sua secretária, que por sua vez retransmitirá a seus subordinados, o elogio ministerial.

\section{Instruções}

$\mathrm{Na}$ discreta biblioteca do gabinete, entre dicionários de vários tipos, há livros com instruções sobre a correspondência e sua técnica. Neles, seus autores se empenham em demonstrar que a redação de documentos oficiais - e por documento se entende tudo - que escrito se incorpora ao universo da função pública - obedece a um sistema em que mestria e técnica são a chave do êxito de quem se empenha em aprimorar-se na correspondência. Os próprios modelos apresentados não dão margem a outro juizo. $\mathrm{E}$ ao redator cabe assimliar e pôr em prática $\circ$ que tecnicamente deve ser seguido.

$\mathrm{Na}$ verdade, as recomendações são valiosas. Referem-se não só ao mundo largo do estilo, alinhando seus atributos, mas ao mundo esquemático e até ascético das estruturas físicas. Ao lado das recomendações sobre a linguagem, outras se impõem, e tratam, menos do contexto, que de sua apresentação. Daí a afirmação do Sr. João Luiz Ney, para quem "a redação administrativa é gênero literário e tem regras como outro qualquer gênero de literatura" (2). Já a estrutura física está amplamente detalhada nas Normas sobre Correspondência e Atos Oficiais 3 , de autoria do Sr. Cauby de Souza, tendo em vista a uniformização e a racionalização dos trabalhos burocráticos.

No mundo do estilo, o Sr. João Luiz Ney alude às qualidades indispensáveis da redação oficial: a correção, a clareza, a concisão, a nobreza, a harmonia, a precisão, a originalidade. Por que tal preocupação estilistica? Responde o autor: "No estudo dessas qualidades gerais, é de toda conveniência prevenir-se contra os defeitos que lhes são correspondentes: impureza, obscurida- 
de, prollxidade, aviltamento, desarmonia, impropriedade e vulgarismo". 4

Já as normas práticas, estas se desenvolvem em oito partes e se assemelham a recomendaçöes que abrangem desde a classificação da correspondência oficial até o sistema de guarda e expedição. De maneira sucinta, sem maiores circunlóquios, a Portaria $n .{ }^{\circ}$ 042, de 24 de janeiro de 1968, trata desses itens: 1 - Tipos de Correspondência; 2 - Atos Oficiais; 3 - Elaboração dos Expedientes mais empregados; 4 - Redação, Instrução, Papéis, Informações e Encaminhamento; 5 - Formas Especificas de Correspondência e Atos Oficiais; 6 - Normas Gerais Datilográficas; 7 Modelos; 8 Controle de Expedição e Recebimento de Comunicações. 5

\section{Ideário}

Em decorrência da existência desses dois mundos tão diversos - o do estilo e o das normas técnicas - que fazer para evitar certas distorções que freqüentemente ocorrem na redação oficial? Impossivel aprendermos seriamente a escrever sem nos inteirarmos das recomendações referidas pelo Sr. João Luiz Ney. Impossível também padronizar a escrita oficial sem pensarmos na feição externa. Imagine-se cada redator escrevendo à sua maneira, dispondo à sua maneira as margens e os espaços datilográficos. Seria - caos. Daí a observação do Sr. Odacir Beltrão: "Se desejamos encontrar no redator brevidade, clareza e naturalidade, queremos ter no documento elaborado por ele as qualidades materiais e imateriais que, harmoniosamen- te combinadas, o colocam entre os padrōes de redação." E acrescenta: "O aspecto, a forma e o conteúdo săo partes de um todo indivisivel, se quisermos obter a perfeição redacional. ${ }^{6}$

Conquanto a teorização em torno da redação oficial tenha chegado a um ponto tão desenvolvido que se admite a existência de um estilo oficial dentro da rigidez técnica recomendada pela Administração, vale a pena observar que, embora tenha havido progresso, não corresponde este progresso à realidade de nossa época. O objetivo das recomendações tanto estilisticas como técnicas repousa num ponto de apoio: tornar a mensagem clara. Dispensa-se o circunlóquio; exige-se a ci. eza. Inútil o palavrório; anseia-se pelo conteúdo. Dispensáveis as perifrases; desejase o pensamento tão perfeito quanto a forma física que possa ele representar. Noutras palavras, inscreve-se como ideário da redação oficial, principalmente nos documentos de informação sumária, aquele requisito essencial vinculado à mensagem: ser bem escrito. “...a linguagem escrita está em essência relacionada com a linguagem literária. Um livro técnico, uma monografia, um artigo de jornal ou de revista não são - nem devem procurar ser - literatura no sentido estrito do termo; mas a ela se ligam pelo cordáo umbilical da sua natureza de trabalho escrito. Por consenso social não escapam de certas exigências de ordem literária". 7

\section{Distorção}

Com a redação oficial ocorre estranha distorção. Para compreendê-la, te- 
remos de analisar, num processo diacrônico/sincrônico, para usarmos a terminologia de Ferdinand de Saussure, aspectos do vocabulário oficial, do ponto de vista evolutivo e do ponto de Vista de sua existência, num dado momento histórico.

A distorção nasce quando se considera estática a expressão escrita de um sistema lingüistico. Certos grupos fraseológicos inicialmente formados com certa imaginação continuam inalterados. Já se perdeu no passado, por exemplo, a origem do adjetivo ilustre (e suas variaçőes) com referência à Palavra senhor. Chegamos até a admitir que as variações adjetivais subseqüentes, a ponto de se alcançar o suPerlativo, foi menos um fenômeno de renovação de significado semântico que um fenômeno provocado pela necessidade de realçar as distinções sociais. Caberia, no caso, uma pesquisa sobre tal adjetivação, porquanto o próPrio ilustre já figura em Camões 8 na precisa acepção dicionarizada. $\mathrm{Na}$ verdade, ilustre, mui ilustre ou ilustrissimo antepostos ao vocativo senhor, já suportaram tamanho desgate de significado, que hoje se incorporam ao anedotário. A história que o Sr. Odacir Beltrão conta, pode não ter lá suas raizes verdadeiras, mas representa, realmente, o descrédito do ilustrissimo abreviado: "Certa vez, perguntaram ao aluno José da Silva por que motivo se inscrevera com o nome de llmo José da Silva. Ele respondeu: - Ora, professor, achei que podia usar isso, Porque todos lá no escritório escreVem sempre ilmo isso, ilmo aquilo..." 9 No entanto, quanto tempo levará ainda a expressão IImo. Sr. nos enve- lopes e na invocação da correspondência comercial e bancária?

Num corte diacrônico, percebemos que ilustre perdeu muito de suas características originais. E se compararmos a altanaria com que Camões o escreveu e a vulgaridade do uso corrente na linguagem coloquial ou mesmo na linguagem epigramática com objetivos inclusive publicitários, vemos a que ponto desceu na escala de valores o adjetivo ilustre, hoje com tão largo trânsito, até pejorativo. 10

\section{A originalidade do lugar-comum}

Por que hoje repelimos certas expressões a que denominamos lugar-comum, a ponto de investirmos contra ele com tal violência que uns extremados, armados de foice, pretendem aboli-lo de uma vez do vocabulário? Pobres lugares-comuns. E que um dia não foram comuns: eram a moeda corrente de valor admirável. Quando ainda hoje escrevemos distinto amigo/aos seus melhores cuidados/preciosa atenção/ tenho a honra de/o assunto em tela/apraz-me acusar o recebimento de/agradeço a significativa colaboração del coloco-me à disposição del rogo a V.Exa. a gentileza de/matéria de tamanha relevância/serão tomadas as devidas providências/no desempenho da missão que the foi confiadal etc., e sentimos como pesam na correspondência (soam falso e nem sempre correspondem ao que desejamos dizer), não nos lembramos que possuiram elas sua dignidade de parecerem originais.

Conta o Sr. Paulo Rónal que certo aluno seu, de latim, confessou seu 
desprezo pela prosa de Horácio, devido aos lugares-comuns. Ao que retrucou o mestre: "Aproveitei a oportunidade para mostrar que a originalidade de Horácio (a não ser que seja um mero tradutor, o que não podemos saber por haver-se perdido grande parte da lírica grega) consistia precisamente em ser ele o pai de muitos lugares-comuns, isto é, conceitos expressos de maneira tão lapidar, tão nova, que se impusram de vez". 11 Sob outro ângulo, penetrante é a lição que nos ensina Marcel Proust, o da reação em face da novidade estética, em certo trecho analítico sobre a personalidade de Bergotte (para alguns intérpretes, Bergotte seria Anatole France): "Aliás, se toda novidade tem como condição prévia a eliminação do lugar-comum a que estávamos habituados e que nos parecia a própria realidade, toda conversação nova, bem como toda pintura, toda música originais, sempre há de parecer preciosa e fatigante. Apoia-se em figuras a que não estamos acostumados, e o conversador só nos parece falar por metáfora, o que afinal cansa e dá a impressão de falta de verdade. (No fundo, as antigas formas de linguagem também haviam sido outrora imagens difíceis de apanhar quando-o ouvinte ainda não conhecia o universo que pintavam. Mas imaginamos desde muito que era $\circ$ universo real e nele nos apoiamos)". 12

Desse assunto se ocupou Flaubert durante toda a sua vida. Empenhavase em elaborar um Dicionário de Idéias Aceitas. Era talvez uma prática que o distraía da suada tarefa de marceneiro que derrubava toda uma floresta para fazer um guarda-roupa, na expressão de Dumas Filho. 13 Não cheguemos a tanto, pois teremos ainda por longo de tempo de conviver com os lugarescomuns até encontrar novas expressões que, por sua vez, para as próximas geraçöes, serão também consideradas lugares-comuns, e assim por diante. O que não nos impede, apesar desse ciclo interminável, de considerar alguns aspectos do problema dentro do esquema de uso corrente, na correspondência oficial.

\section{A grandiloqüência epistolar}

Como nos libertamos do lugar- $\mathrm{CO}^{-}$ mum? Como evitar a pressão das frases feitas que se assemelham às flaubertianas idéias aceitas?

Todo o esquema referido pelos que estudam a lingua e recomendam uma linguagem precisa, está de pé. Mas, entre a teoria e a prática a distância por vezes é tão grande quanto a que separa o carro-de-boi do foguete Apolo. Quando escrevemos, estranho fantasma ressuscita de nosso subconsciente toda uma fauna de duendes, a ponto de atravancarem a folha em branco e atulharem o chão ou a cesta, de bolinhas de papel. A idéia fica emperrada e só encontramos uma saída para nos desobrigarmos: recorremos ao arquivo e lá está para tal assunto o seu modelo. Então a tarefa se torna mais fácil e, escrito o primeiro parágrafo, o resto se desenvolve com certa naturalidade.

Entretanto, em virtude do primeiro embalo, o estilo terá de ser uniforme. Prosseguimos no mesmo tom em que as idéias, engomadas, adjetivadas, 
cheias de ancilas de reforço, essas expressões que tanto empurram a frase para a frente - as conjunções, as locuções adverbiais e prepositivas nos levam até o final onde chegamos extenuados pelas cascatas verbais. E é com tranqüilidade que voltamos a copiar já em plena ascensão à superficie, à procura do ar puro da linguagem coloquial, o fecho grandiloqüente: "Aproveitamos a oportunidade para renovar a Vossa Excelência..."

Se observarmos a grandiloqüência epistolar do estilo oficial, veremos que sentimos uma atração tão sensível pelos epitetos, que julgamos magra e anêmica a expressão em que um substantivo não se encontre amparado pelo adjetivo correspondente. Quando procuramos dar maior expressividade, saPecamos um adjetivo: um escritor não Parecerá simplesmente escritor, mas renomado escritor. Raro o prefeito a quem não se diz, em telegrama de cumprimentos, que o municipio sob Sua administração é próspero. E a ninguém que tenha recebido uma missão no País ou no exterior se deixará de dizer ter sido ou que será honrosa ou espinhosa. As mensagens de luto semPre são confortadoras. E de um embaixador com representação oficial, dir-se-á que inúmeros são os laços que nos unem a essa grande nação-irmã. Nenhuma autoridade, ao instaurar inquérito, designando a comissão, deiXará de adjetivá-lo: que o inquérito seja rigoroso.

\section{Substantivo/Adjetivo}

Que fazer? Há muito o que fazer, a começar por uma revisão de conceitos que nos preparem para ver a palavra escrita com outros olhos. Mas a primeira atitude será a de cortar na carne - que é supérfluo e empenhar-se em procurar, em vez do adjetivo, o "substantivo expressivo que contém Já em si um elemento de caracterização", no dizer do Prof. M. Rodriguse Lapa.14 Para o autor de Estilistica da Lingua Portuguesa, o substantivo não difere muito do adjetivo. $E$ acrescenta: "A própria origem do nome tem mais de adjetivo do que de substantivo. Com efeito, ao princípio, todos os seres foram designados por uma qualidade fundamental que os caracterizava" 15

Embora a tese encontre fértil debate no campo da polêmica, à luz das teorias lingüisticas modernas, sempre verificamos uma tendência nossa de, através de comparações, estigmatizar o significado do que pretendemos batizar. Basta imaginar a forma fisica de objeto correspondente a algumas palavras - couve-flor, aguardente, automóvel, vaga-lume - para percebermos que a relação substantivo-adjetivo é mais qualitativa que nominal. Daí a tendência para se substantivar o adjetivo, dando-se à qualidade uma função bem apropriada, como se lê em Euclides da Cunha: "O sertanejo é, antes de tudo, um forte". 16 Ou de se adjetivar o substantivo, com a inclusão de referências estritamente nominativas. Veja-se este trecho de diálogo: "Um dia dei uns toques a D. Glória:/ - Por que é que sua sobrinha não procura marido?/ Melindrou-se:/ - Minha sobrinha não é feijão bichado para se andar oferecendo". 17

Maior ainda a semelhança semântica na área do significado, quando num 
coloquial de traços realistas, numa época em que havia empenho em se escrever como se falava, a tia Sinhazinha, em Doidinho, esgoelava-se da manhã à noite: " - Zé Paulinho não sabe educar. Não tem coragem de meter o pau. É um banana" 18 Ou então este traço adjetivo num substantivo de variadas conotações: "Aquela intimidade de vizinhos tinha de acabar nisto, que é verdadeiramente uma bênção do céu, porque ela é um anjo, é um anjissimo... Perdoe a cincada, Bentinho, foi um modo de acentuar a perfeição daquela moça".19

Não quer dizer, entretanto, que vamos jogar o adjetivo porta a fora ou janela abaixo. Não vamos enxotá-lo como se fosse um imprestável, um inútil, sem serventia. (Pois acabamos de usá-lo com função substantiva...) Vamos, sem dúvida, afastá-lo de nossos clichês mentais, que por sua vez determinam a linguagem escrita.

Um escritor da categoria de Camilo Castelo Branco, há mais de século, em crônica escrita em 1858, fazia estas observações sobre o jornalismo da época, e que certamente correspondia à linguagem escrita e à oratória em curso, a propósito dos clichês fraseológicos: "Obriga-se o cronista a manter invariáveis os seguintes adjetivos, quando vierem usados para os seguintes substantivos: Prelado será sempre virtuoso; cantora será sempre mimosa; iornalista será sempre consciencioso; jovem escritor será sempre esperançoso; patriota será sempre eximio; negociante será sempre honrado; caluniador será sempre infame. As maneiras de quem dá um baile serão sempre amáveis; os convidados sairão sempre penhorados. O folhetinista será sempre espirituoso; 0 poeta será sempre inspirado. Os irmãos terceiros serão sempre veneráveis. Os sócios de qualquer coisa mercantil serão sempre acreditados. Os meninos recém-nascidos serão sempre robustos. As viúvas seräo sempre inconsoláveis... Se o ricaço der doze vinténs aos inválidos, este feito será sempre um rasgo filantrópico, e a fortuna dele será sempre abençoada. Não haverá baile que não seja animado, nem jantar que não seja lauto, nem serviço que não seja abundante, ou profuso, para variar. Nenhum homem rico terá amigos que não sejam numerosos. Todas as firmas da praça comercial serão sempre respeitáveis. O voto de qualquer parvoinho será sempre ilustrado; e mais depressa morrerá o cronista do que deixará de ser eloqüente o discurso de qualquer Cicero fanhoso. Todo o casamento será próspero. Ninguém poderá morrer que não fique sendo bom cidadão, bom pai, bom marido, e terá tudo bom". 20

Se formos confrontar a adjetivaçăo respigada por Camilo Castelo Branco e a do jornalismo de nossos dias, veremos que muita coisa mudou. Mas, quem quiser pesquisar alguns de nossos jornais do interior, muito beletrista (que acumula as funções de diretor, redator-chefe, redator e responsável pela publicidade) traz em seu arsenal lingüistico as firmas respeitáveis, os sócios acreditados, os poetas inspirados e os prelados virtuosos. E de tal modo se precavêm os editores e secretários de jornal, que, em recente livro sobre o estilo jornalístico, o jor- 
nalista Lago Burnett sentenciou: "Não devemos ter nenhum preconceito com as palavras, quando elas são as únicas apropriadas para exprimir o nosso pensamento no ato de escrever. Por favor, não pensem que estou aqui, teatralmente, defendendo o palavrão na imprensa. Repudiaremos sempre as expressões chulas, as de mau gosto, os arcaísmos, os neologismos não oficializados e os eufemismos. Nunca recorreremos ao titular da pasta do Interior, aos soldados do fogo, aos edis, ao primeiro magistrado da Nação, ao astro-rei, quando é mais simples e mais correto falar do Ministro do Interior, dos bombeiros, dos vereadores, do Presidente da República, do sol. Pertinaz moléstia e mal súbito são também diagnósticos que não devem ser feitos por bons jornalistas. Nem por bons médicos. Tomar um café é melhor do que saborear a rubiácea. Precioso liquido é água mesmo". 21

Se a própria imprensa mantém vigilância diária em favor da expressividade, por intermédio de jornalistas esPecializados (formam o copy-desk da redação), maior razão no serviço público se justifica qualquer providência em favor de uma linguagem mais desPojada dos excessos verbais. Pois o objetivo é sempre o mesmo: transmitir, seja o que for, com a maior clareza.

\section{Expressão escrita e expressão oral}

Ao lado, porém, do adjetivo surrado, de homérica idade, outro fator de distorção na linguagem oficial se apresenta, principalmente, quando o redator sai da correspondência um tanto medida e contada, de formulário pron- to - uma comunicação, um requerimento, um aviso, um memorando - e entra na faixa mais ampla de uma exposição ou de um relatório. Aí os veIhos duendes se apresentam como se fossem legião. $E$, numa tentativa de tornar bem expressa (não dissemos expressiva) a mensagem, o redator procura convencer o eventual leitor, através de um esquema verbal onde o que mais sobreleva é o preciosismo.

Neste ponto, estreita-se a relação entre a expressão escrita e a expressão oral. Não vemos como torná-las distintas, quando, na realidade uma e outra se irmanam, se mesclam, se interpenetram, e ficamos por vezes sem saber se o redator é orador ou se o orador está ditando um texto.

Costumam os exegetas da oratória afirmar que a eloqüência adquire foros de perenidade quando se torna digna de leitura; quando vence a prova da leitura, ou seja, o texto escrito. Num dos poucos livros sobre a matéria, à maneira de ensaio, o Sr. Josué Montello afirmou que a "expressão oral é apenas uma das das dimensões da oratória. A outra é a escrita, que lhe dá perdurabilidade e categoria literária. Nem sempre as duas expressões se correspondem. $O$ orador, na tribuna, é um; pode ser outro no papel impresso". 22

A reciproca é verdadeira. Tome-se uma exposição de motivos bombardeada de eufemismos, de metáforas, de preciosismos, e veremos o leitor perdido já no terceiro parágrafo, indagando-se o que 0 autor quer dizer. Ou, na melhor das hipóteses, corren- 
do rápido os olhos para os últimos parágrafos, a fim de saber o que o autor deseja. Nem a leitura dinâmica salva um péssimo texto, do ponto de vista da compreensão e da clareza.

Entrelaçam-se, portanto, as expressões escrita e oral, embora os vicios que lhes são comuns repontem mais vigorosos, quando se submete o texto à leitura. Mas, onde a origem, a gênese da tosca oralidade e mais tosca redação?

\section{Pensar e escrever}

Essa oralidade tosca e esse tosco oficio de espichar-se um parágrafo indefindamente, resulta menos das tendências pessoais de cada um do que da falta de hábito de escrever, ou meIhor ainda, de pensar. De criar idéias. De coordenar os pensamentos e afinal dizer-se: é isto o que desejo expressar. Depende menos do talento de escrever ou de falar do que da organização interior dos pensamentos. Da faculdade, diremos, de saber pensar. Não insinuamos que o principal requisito de quem escreve deva ser o de comportar-se como pensador - um arquiteto de idéias. Absolutamente. Pensar, admitamos, no sentido mais trivial: ter alguma coisa na cabeça para dizer. $E$, principalmente, pensar com o objetivo de coordenar a expressão, seja oral, seja escrita.

É truismo esta afirmação: quem pensa mal, não terá condiçōes de expressar-se bem. Este truísmo, tão antigo quanto o homem em sua luta pela Comunicação com os outros homens, ainda continua em pauta. Por que?
Porque o ato de escrever é estritamente pessoal. É uma experiência de cada um. Semelhante ao amor, ao ódio: $\mathrm{so}^{-}$ mente quem viveu esses sentimentos alcança até onde vai o homem quando ama ou odeia. Não importa aprender, muitas vezes, a arte de redigir. Esta, os gramáticos sabem-na de cor e salteado. Conhecem profundamente as regras e exceções no emprego da partícula se e sobre isto são capazes, têm competência de escrever tratados. Entretanto, não é o conhecimento gramatical que abre as portas da expressividade oral ou escrita. É a velha arte de saber coordenar as idéias: a arte de pensar. E curioso, muito curioso, insistimos, não existir ainda em nossas escolas uma matéra que, desde o curso primário, oriente o aluno para a admirável arte de pensar sem a qual nada se pode fazer. $\mathrm{E}$ quando somente na adolescência ou na idade madura a criatura humana começa a descobrir este seu mundo interior, então percebe o quanto de tempo perdeu, e embora, à maneira proustiana tente recuperar 0 tempo perdido, vê que muitos hábitos mentais têm raizes de goiabeira no chão esquecido do inconsciente.

A relação pensar-escrever, em nossa época, oferece subsídios para um trabalho especial. Fiquemos, porém, no registro de indiscutivel comprovação, a ponto de, qualquer texto sobre a matéria, conter, ao menos em sintese, esta opinião de W. Somerset Maugham, em suas Contissões: "Mas suponho que se um homem tem o espirito confuso, escreverá de modo confuso" 23 Por que isto acontece? Embora se referisse a pessoas que jamais deviam incidir na obscuridade, e estão nesse 
caso os escritores profissionais ou bissextos, 24 Maugham dizia que uma das causas "é que o próprio escritor não está perfeitamente seguro do seu pensamento. Tem uma vaga impressão do que quer dizer, mas, ou por falta de poder mental ou por preguiça, não o formulou exatamente em seu espírito, e é muito natural que não ache uma expressão precisa para uma idéia confusa. Isso provém do fato de que muitos escritores pensam, não antes, mas enquanto escrevem" (25).

Se isto acontece a escritores que confiam no poder da improvisação, por que não com o nosso redator oficial, que por vezes não sente o que, por.tarefa, the fol encomendado? Porque o sentir o tema, no caso do profissional a que refere Maugham, é para muitos meio caminho andado. O escritor não é um burocrata que termina seu expediente ao pôr-do-sol. O escritor, seja de ficção, seja ensaísta, seja mesmo 0 jornalista do quotidiano com a missão de interpretar os fatos, ele vive $\mathrm{e}$ convive com os seus personagens, suas idéias, suas notícias. Até dormindo o escritor trabalha; seu inconsciente remói o moinho da criação, e os personagens, as idéias e as notícias se encravam no outro eu que, pensando, trabalha. Daí certos escritores escreverem bem sem nenhum plano de trabalho: dispõem-se a escrever e a prosa sai fluente.

Ora, o redator de correspondência oficial se não tem a obrigação de viver - dia-a-dia burocrático, como parte integrante de sua personalidade, deVerá compensar esta vivência interior com uma disposição para assimilar e transmitir o que the é recomendado executar. $\mathrm{E}$ aqui a ordenação do pensamento se estabelece na base de planos de execução. Execução que obedece, inicialmente, a esquemas condicionados ao tipo de trabalho que se vai redigir.

Um memorando não exige a mesma estrutura do ofício; e um ofício está separado, de muitos furos, do memorial ou da exposição de motivos. Quando não se compreende isto, do ponto de vista estrutural, cometem-se os mesmos enganos que tanto ocorrem na redação jornalistica: confunde-se um editorial com uma noticia; uma nota com uma reportagem. E se na mesa do jornalista tais enganos resultam em bolas de papel na cesta ou em certo nervosismo do secretário-de-redação que irritado com o "foca" 26 termina por ingerir duas xícaras de café fora do horário antes de perder a paciência, num gabinete ou seção ministerial esses desencontros de interpretação do texto apenas depõem contra o funcionário. E o chefe de gabinete, indagando à sua secretária onde anda o oficio, se já ficou pronto, poderá ouvir: "Não senhor, estou refazendo. O senhor não conhece a dificuldade de se encontrar um funcionário com redação própria?"

\section{A magia do preciosismo}

Alie-se a uma deficiente ordenação de pensamento - e mais deficiente se não houver um plano de trabalho, principalmente nos documentos oficiais mais longos - a influência da oralidade, de consequeências negativas para o estilo, ou melhor, para a comunica- 
ção do acontecimento oficial. A mais séria: o preciosismo.

Lembro-me, como se fosse hoje, de acontecimento que presenciei, aos treze, quatorze anos. Meu pai e meu tio conversavam sobre a redação de uma carta, requerimento ou o que seja, a ser encaminhado ao prefeito, a propósito de conserto no serviço de águas - a pena d'água, como se dizia. Há três dias não pingava uma gota do precioso liquido, como se dizia no jornalismo da época. Mas a discussão nasceu em torno do cumprimento à autoridade, ou melhor, de como iniciar a carta, em nome dos moradores da rua, para que Sua Excelência, o Sr. Prefeito, tomasse "as devidas providências". O impasse surgiu logo no inicio. Lembro-me que meu tio, de caligrafia treinada no paleógrafo 27 assim começou: "Tenho a subida honra de cumprimentar Vossa Excelência..." Meu pai, no outro lado da mesa, não concordou. Não concordou com subida. Veio a dúvida de pronúncia: subida ou súbida? Meu pai não sabia. Foram ao dicionário, um Jayme Séguier, capa cor-de-rosa, antigo. Não "leva acento"; logo, devia ser subida. Meu tio, a essa altura, também não sabia qual seria a exata pronúncia. Mas havia também muitas palavras de pronúncia tônica, sem acento. Súbida ou subida? Deixaram mesmo sem acento, "como está no dicionário", embora a dúvida prosódica ficasse. Dúvida que me acompanhou por muito tempo, porquanto, na imaginação da criança, considerasse incrivel que se falasse em subida escrevendo-se ao "seu" Prefeito. Ora, subida, a subida que eu conhecia, era coisa semelhante à ladeira, perto de lá de casa. Para que escrever subida em assunto de prefeito e pena d'água?

O preciosismo possui certa magia. Sempre nos inclinamos a dar à frase uma grandiloqüência que somente as palavras dificeis ou de pouco uso têm condições de criar. Consideramos tacanho, pífio, o vocabulário tradicional, aquele em que nos comunicamos, $e$, em face principalmente da Autoridade, admitimos que não se deve, em absoluto, escrever como nos expressamos. Daí a angustiada procura de palavras que, no mínimo, confere a quem as escreve uma categoria intelectual mais elevada.

\section{Uma Pesquisa de Lobato}

Quando exageramos, acontece o desastre. Monteiro Lobato conta certa experiência com um texto de Coelho Neto. Conversava com Artur Neves, da Cia. Editora Nacional, sobre o que certos escritores fazem e que necessitam ser traduzidos. Sobre a mesa, havia a reprodução de um artigo de Coelho Neto sobre José do Patrocínio. Disse Lobato a Artur Neves: "Eu derrubo este seu lápis vermelho em cima e juro que a ponta marca uma frase que tem de ser lida traduzidamente". Feita a prova, a ponta caiu nesta frase: "Pela estrada desciam récuas em chouto, sacolejando ceirões e cotos". Lobato continua:

“- Bem. O artigo trata da última visita que Coelho Neto fez a Patrocínio, já quase moribundo, lá numa casinha de Piedade, subúrbio do Rio de Janeirro. Ora, quem conhece este pals, 
e o Rio, e os subúrbios do Rio, sabe que por cá não existem récuas, nem choutos, nem ceirões, nem cotos. Tudo isso são velhas tintas lusitanas que Neto usava para pintar paisagens daqui. O leitor, portanto, terá que verter tais tintas para as equivalentes nacionais - mas só o fará se for culto e bem dotado de paciência. Em caso contrário, repele o autor, dizendo, "Outro oficio!" Mas traduzindo em lingua comum a tremenda complicação acima, - que obtemos é muito simples: Pela estrada desciam burros de carga no trote, sacudindo jacás. Como você está vendo, o trabalho é duplo; é um trabalho de leitura simultaneamente articulada com tradução mental".

Manuel Neves, assistente de Artur Neves, que ouvia a conversa, achou que Monteiro Lobato estava exagerando. Lobato fez outra experiência com - lápis. E a ponta caiu neste trecho, no mesmo artigo: "Deixando o trem, meti-me por uma estrada cheia de sulcos de carros e covas que eram atascais. A um lado, alta, escalavrada, a barranca sanguinea eriçada de mato, com cercas de espinhais em flor defendendo pomares; em frente, casario roceiro, com alpendrada e poiais, argolòes em esteios, mastros com bandeirolas."

E com admirável humor, Lobato falou para Manuel Neves:

"- Veja, seu Manuel, quanta coisa há neste período que exige tradução. Estradas com covas, não sei o que sejam. Covas só temos no cemitério ou feitas em horta para a plantação de mudas. Nossas estradas têm apenas buracos. E não há buracos de estrada com atascais dentro. Elas têm nos buracos apenas lama, ou tijuco, ou barro. Também não temos à beira das estradas pomares - temos quintais com umas tantas laranjeiras cobertas de erva-de-passarinho, umas bananeiras, umas goiabeiras e um pé-de-mamão. Isso não dá pomar - dá apenas um simples quintal com árvore, coisa muito diferente. E esta cerca de espinhais em flor? Temos cercas vivas de pinhão do Paraguai, e mesmo de espinheiro. De espinhais, nunca vi. E este em flor é uma eterna superfetação - como os seios túrgidos nos romances de Veiga Miranda. Para Coelho Neto tudo era em flor - a balsamina em flor, a boca em flor. Para Veiga Miranda tudo eram seios túrgidos. A gente tem de ir traduzindo os dois - tirando aquelas flores e pendurando aqueles seios, para visualizar a realidade descrita. E a barranca sanguinea? Não há disso! Nossas estradas só têm barranco vermelho. Também não há mato eriçado - o que eriça é espinho de ouriço e outras coisas duras e pontudas mato não é duro nem pontudo. $E$ esse casario roceiro com alpendradas? Não temos nada disso. Um subúrbio do Rio ainda não é bem roça, e nenhuma daquelas casinhas tem alpendrada terá quando muito uma pequena varanda. Os tais argolões em esteios a gente só os vè nos currais, para amarrar burro bravo. E os tais poiais, raros leitores saberão o que é. Temos de traduzir para banco tosco. E esse mastro com bandeirolas? Haverá por lá mastros de São João, os quais não usam bandeirolas e sim bandeira de santo. Bandeirola é uma pequena bandeirola solta ao vento; bandeira de 
santo é um rígido quadro de sarrafo com o retrato dum santo fogueteiro, $\mathrm{S}$. João, Santo Antônio ou S. Pedro, estampado em morim e ali pregado com tachinhas. Não há no Brasil inteiro um só mastro com bandeirola. Está vendo, Manuel, quantas traduções neste segundo período indicado pelo lápis?... Quer mais umas pingadas?

Manuel ficou com medo e desistiu de terceira experiência". 28

Para compreendermos essa quizila com o estilo rebarbativo, basta dizer que Monteiro Lobato era desses escritores que não dissociava a expressão oral da expressão escrita. Uma e outra se completavam. Muito jovem ainda, na fase de aprendizado, nos idos de 1915, em carta a Godofredo Rangel, escreveu, a propósito de um pronome mal colocado: "Quanto ao meu erro do se o pratica, é coisa tão soez e chata que escusava te alongares tanto na demonstração. Já o expungi. Não fujo à pecha de ignorante em gramática, e até proclamo essa ignorância. $E$ na realidade guio-me pelo tacto e o faro, pelo aspecto visual e auditivo da frase. Se algum período me soa falso, releio-o em voz alta para perceber onde desafina. $E$ achada a corda bamba, não a analiso, dispenso-me de saber que preceito gramatical foi ali ofendido: aperto a cravelha e afino a frase. 0 método não será dos melhores, mas é o meu". 29

Para que maior influência do preciosismo do que na oratória? Sob qualquer pretexto larga-se o verbo e todas as potestades são mobilizadas. Perdura ainda o estilo nefelibático. Seja na oratória de brindes no final das re- cepções, seja na conversa de Eulálio Relvas, revisor do Correio do Recife, com o diretor, Felipe Gama: "Preliminarmente, desejo reiterar-vos os meus profundos agradecimentos em face do privilégio que concedeis, todas as noites, a este vosso amigo, admirador $e$ servo: o de ser o primeiro leitor consciente dos vossos artigos magistrais, de vernáculo castiço, os quais, quer isoladamente, quer no conjunto, significam a bússola orientadora da opinião pública, nesta conturbada fase da nossa vida político-administrativa. Este representa um salário intelectual inatingivel em quaisquer outros órgãos ou postos da imprensa indigena". $30 \mathrm{E}$ a conversa de Eulálio Relvas com 0 diretor do jornal se esparramou, na prosa ágil de Mauro Mota, até o desenlace: queria passar um vale.

\section{TÉCNICAS DA COMUNICAÇÃO NA REDAÇÃO OFICIAL}

Pensar. Escrever. Falar em público. Conversar. Redigir oficios, mensagens, cartas, telegramas, memorandos. É um ciclo imenso que se entrelaça.

Tratando-se da redação oficial, além dos problemas vinculados com a Estilistica, outros aspectos adquirem em nossa época maior realce. Como tornar a redação oficial mais atual e afim com as técnicas da Comunicação?

Pode parecer estranho elevar um offcio, uma exposição de motivos ao nivel de instrumento de Comunicaçăo. E mais estranho ainda se quisermos ir mais longe: estender um provável confronto entre um memorial e uma matéria jornalistica. Tão diversos - di-se-á 
- o papel timbrado e o jornal, que em nenhuma hipótese se pode aceitar tal similitude.

Mas a estranheza desaparece quando abrindo um jornal moderno, encontramos uma seção, na página editorial, com este título: Cartas dos Leitores. Então, como ocorre no episódio proustiano das madalenas à hora do chá, para quem medita sobre o tema da Comunicação humana, essa coluna à disposição dos leitores evoca um mundo - o próprio universo da presença do homem na face da terra, empenhando-se em transmitir, sempre transmitir - que lhe acontece, seja nas quatro paredes de seu lar, seja nas quatro muralhas da cidade, seja nos quatro pontos cardiais.

A Comunicação, ontem e hoje, sempre foi condição de existência. E aqui percebemos que a distância entre o fogo, o tantã dos homens primitivos e o jornal que recebe as notícias via satélite tem um nome: progresso. Em pleno progresso, possuindo todo um aparelhamento tecnológico de excepcionais possibilidades de transmissão de mensagens, ainda hoje o homem utiliza a fumaça para expressar decisões da mais alta repercussão mundial: a esColha de um papa. E quando as questões intrincadas não permitem que o próprio telefone vermelho entre a $\mathrm{Ca}$ sa Branca e Kremlin seja o veículo Ideal para solver as divergências, que fazem os estadistas? Marcam encontros pessoais. Vão aơ tête-à-tête. Conversam dois, três, quatro dias seguidos. Conferenciam. Imitam simplesmente os homens da História Antiga. Num arremate clássico, terminam fir- mando documentos (acordos, tratados, convênios); e assim o homem de Governo, para usar a expressão machadiana, termina atando "as duas pontas da vida", tendo ao lado o funcionário público, redator de documentos oficiais, versão moderna dos escribas e profetas, sejam eles redatores, sejam assessores com assento privilegiado Junto aos faraós do nosso tempo - os homens de Estado.

\section{Nota Oficial e Notícia}

Antes do jornal, que representava a correspondência oficiál ou particular, no mundo antigo? Qualquer compêndio de História da Comunicação não deixa de incluir sobre este aspecto um exórdio. É de Fernand Terrou esta observação que certamente não aprendemos em aulas de História: "o soldado de Maratona não é apenas um exemplo esportivo". 31 Marco Polo - informa ainda Terrou - encontrou mais de 200000 cavalos em serviço de entrega de correspondência, no Império dos Mongóis. E o que era a correspondência em sua origem, senão um veículo de expressão do que se passava entre os homens? Ainda hoje, na linguagem do quotidiano, quando alguém recebe uma carta enorme, de cinco, seis, dez, quinze laudas, o destinatário não se contém e diz: "- Puxa! Isto já deixou de ser carta, é um jornal!"

$\mathrm{Na}$ realidade, os jornais antigos não passavam disto: registravam os acontecimentos. E se muita coisa mudou, do ponto de vista técnico, em sua essência o homem é um curioso incorrigivel.

Se os Jornais apresentam modificações constantes, e ainda se modifi- 
cam diariamente, com o objetivo de alcançar maior público, transformando-se em pouco tempo numa indústria das mais poderosas do mundo, a correspondência, limitada ao tamanho dos envelopes, não se preocupou com este aspecto. Se o jornal é uma extensão da correspondência e a correspondência, em seus primórdios, foi uma das primeiras "extensões do homem", para usar a expressão de McLuhann; se o jornal ainda hoje tem de criar novas formas de apresentação das noticias, vive sempre modernizando-se à procura de novos processos de tornar a notícia mais atraente, na correspondência não existe, a rigor, essa preocupação. Não é a correspondência objeto de venda. Não é mercadoria. É um veículo pessoal, de comunicação direta, e ainda que por vezes se denomine circular, na essência o assunto alcança determinadas faixas de público. Um edital abrindo concorrência pública para a construção de uma ponte é tão diferente quanto 0 mesmo edital transformado em notícia. Dentro de um ângulo jornalístico notícia é ainda a inauguração da ponte ou, na pior hipótese, a sua destruição por uma enchente. Simples exemplo que oferece uma visualização da dinâmica verificada ná imprensa e da cristalização da forma na correspondência oficial.

Temos ainda hoje um veículo em que a linguagem oficial coexiste ao lado da linguagem jornalistica. Basta ler um Diário Oficial, em que se publicam os atos do Governo redigidos nos padrões usuais da Administração Pública e estes mesmos atos transformados em noticia. Veja-se a diferença. Confronte-se, distinga-se a linguagem. Em al- guns órgãos oficiais, a exemplo do Distrito Federal, órgão oficial do Poder Executivo do D.F., o estilo administrativo corre paralelo com o estilo jornalístico. Lê-se o ato público. Mas, para melhor compreensão, recorre-se à informação contida na notícia ou na reportagem. Altera-se a estrutura do ato normativo, procurando-se traduzilo, com vistas a uma interpretação do texto legal.

Tal prática significa, em nossa compreensão, um avanço admirável. $O$ ato normativo possui uma estrutura própria, rígida, adequada ao espírito codificante. O pensamento do legislador se distribui de acordo com as normas técnicas: o artigo, o parágrafo e desdobramento - incisos, itens, alíneas. Artigos e parágrafos que se agrupam em seção, capítulo, título, livro, partes geral e especial. Em recente estudo sobre a matéria, o Prof. José Afonso da Silva "entende por apresentaçăo material do ato normativo (também do individualizado) a distribuição do assunto no seu texto". Mas não esquece o aspecto da redação que deve ser "correta, simples, precisa e concisa". E mais: "Para que o texto se apresente sistematizado logicamente, o redator do ato deve, desde o projeto ou minuta. fixar bem o que pretende regular, tomando cuidado para que não sejam incluidos dispositivos contraditórios, confusos ou incoerentes, isto é, que o conteúdo de um dispositivo não exclua o de outro, nem que o conteúdo de um divirja do de outro, nem contenha matéria estranha ao assunto que está sendo regulado". 32

Não houvesse duas ou três palavras que identificam de logo a recomenda- 
ção como dirigida ao redator de atos oficiais, diríamos que se destinaria a qualquer aluno de português, a quem se the solicitasse uma dissertação sobre as principais correntes literárias, a partir do século XIX. Vê-se, pois, que as fronteiras dos atos oficiais, da correspondência oficial e da narrativa jornalistica são tão afins, que o aproveitar as virtudes de uma para corrigir os defeitos de outra contribui para 0 objetivo comum: a melhoria dos padrões da comunicação escrita.

\section{O impacto inicial}

No campo da expressividade, esta aproximação da correspondência com - Jornalismo se fundamenta num fato que é um dos pontos mais apaixonantes da comunicação escrita, em qualquer gênero, e que diz respeito ao objetivo de quem escreve: fazer com que o leitor vá até o fim. No jornalismo, são conhecidas as técnicas de redação que, incluindo o título, trazem a finalidade de despertar o leitor $e$, sem esforço, levá-lo a ler toda a notícla. Qual o segredo?

O segredo está no impacto inicial. Dispensam-se os rodeios, os circunlóquios, o antigo nariz-de-cera, entra-se no assunto. Começa-se pelo tema principal, o climax, e, a seguir, desenvolvendo-se a matéria, revelam-se os pormenores.

Admitamos que o Diretor do Departamento Administrativo do Pessoal Civil (DASP) convoque a imprensa para uma entrevista. Qual a técnica a ser aplicada na redação do acontecimento? Precisamente aquela que possa responder, de imediato, à curiosidade do leitor: que aconteceu? Em nenhuma hipótese se redigiria a notícia informando que, aproximadamente às tantas horas, em seu gabinete, o Sr. Diretor do DASP iniciou a entrevista. Estavam presentes os senhores sicrano e beltrano, seus assessores. Os jornalistas começaram a fazer perguntas. A primeira, foi a seguinte... $E$ assim por diante, numa narrativa tranqüila do fato.

Absolutamente. Nenhum jornalista daria à entrevista essa forma de relato, como se fosse um depoimento ou como se o repórter se comportasse como testemunha. O Diretor do DASP, ponto central da entrevista, teria certamente de revelar algo importante para a Administração Pública na faixa de suas atribuições. E ○ mais importante, sem dúvida, seria o começo, a cabeça, o lead da notícia: "- o Serviço Público será totalmente reestruturado, através de plano já encaminhado à Presidência da República, e que marcará o início, em definitivo, da Reforma Administrativa", informou ontem, em entrevista coletiva, o Diretor do DASP, Prof. Glauco Lessa de Abreu e Silva". A seguir, viriam os pormenores do plano, sua implantação, aspectos esclarecedores do problema. E viriam também as indagações, as respostas; enfim: tudo aquilo que esclarecesse melhor o principal Já referido: a reestruturação do Serviço Público: Esta é a técnica da pirâmide invertida.

Procuremos transplantar esta técnica da objetividade visual, imediata, do jornalismo, para a correspondência oficial e perceberemos que muitos circunló- 
quios tenderão a desaparecer. Sem quebrar as normas técnicas da feitura tradicional do ofício, do memorando, da exposição de motivos, o que tivermos - que informar poderá ser dito no primeiro parágrafo.

Quando Bernice C. Turner em seu livro sobre correspondência comercial apontou a existência de três estilos de redação na área dos negócios - o estilo artigo, o estilo noticia e o estilo anúncio - estava tocando no assunto, apesar de sua terminologia pouco jornalística. 33

Entende a autora por estilo artigo o que se constrói devagar, com um climax no final da mensagem; por estilo noticia, o que principia incisivamente e a seguir detalha 0 assunto; e por estilo anúncio, o que procura, tanto quanto possivel, usar a linguagem publicitária, em que as palavras traduzam "imagens e movimentos".

Apesar de imaginosa a aproximação estilistica, algumas ressalvas se fazem quanto à definição dos estilos. Num artigo de jornal a construção não se faz devagar até atingir o climax. Isto acontece com a noticia e a reportagem, quando escritas noutra técnica de pirâmide, a pirâmide tradicional. Narrase um fato como se fosse um conto tradicional à Maupassant e à Maugham, com principio, meio e fim. Uma reportagem semelhante às histórias verídicas do quotidiano. Tratando-se ainda de noticia, vale dizer que se pode também construi-la (o que pode ser válido em certos documentos oficiais) em pirâmide mista: começa-se com o climax, o aspecto importante do fato e, a seguir, elabora-se a narrativa contando como o fato aconteceu, por ordem cronológica.

\section{O tripé da comunicação}

Aproximação mais acentuada das técnicas de redação na correspondência e no jornalismo poderá ser feita, se a considerarmos, dentro de uma visăo mais ampla que não pertence apenas à informação pura e simples, mas à interpretação e à opinião.

Tentemos, inicialmente, definir o que seja informar, interpretar e opinar, na linguagem jornalistica. Tema polêmico, divide mais de uma geração de profissionais de imprensa. Partindo de uma notícia dada - aquela em que 0 Diretor do DASP anuncia a reestruturação dos servidores públicos - vejamos o que se entende, na terminologia jornalistica, por informação, interpretação e opinião.

Informação - a notícia pura e simples do fato, ou seja, do que disse 0 Diretor do DASP na entrevista. É o registro.

Interpretação - esta mesma noticia dentro de uma nova dimensăo. Procura-se dar ao leitor uma idéia, mais completa possivel, do que significam as informações prestadas pelo Diretor do DASP. Há jornais (em nossa imprensa, o Jornal do Brasil) que recorrem ao Departamento de Pesquisa, que fornece ao redator elementos, facilitando-the a tarefa de elaborar uma $\mathrm{ma}^{-}$ téria especial sobre o problema da reforma administrativa no Pais. Dispondo de informaçőes colhidas em jor- 
nais de épocas anteriores, o redator poderá fazer um levantamento geral do assunto, já cogitado pelas administrações anteriores. É a interpretação uma série de informaçōes suplementares pelas quais o leitor tomará conhecimento do tema, ficando mais a par do que se passa.

Opinião - é o pensamento do jornal. Na coluna dos editoriais, o jornal dará sua opinião sobre a entrevista do Diretor do DASP.

Lester Markel, diretor dominical do New York Times, citado por John Hohemberg, perante o Instituto da Imprensa Internacional, definiu o que seja o tripé da comunicação jornalistica:

"Informar que o Kremlin esta lançando uma ofensiva de paz, constitui noticia.

"Explicar porque o Kremlin põe as pombas a arrulhar precisamente nessa ocasião, constitui a interpretação.

Declarar que qualquer oferta de paz do Kremlin deve ser rejeitada sem mais estudo é uma opinião".

E arrematava:

"A interpretação constitui parte essencial da coluna noticiosa. A opinião deve ser limitada, quase religiosamente limitada, à página editorial. Trata-se do Ponto básico ao qual não se pode deixar de dar o necessário destaque". 34

O tripé na correspondência oficial $\mathrm{Na}$ correspondência oficial, há documentos em que a Autoridade ora in- forma, ora interpreta, ora opina. Ou, em alguns casos, informa, interpreta e opina; ou apenas fornece elementos de interpretação, com base em informações.

Segundo os princípios acima referidos, procuramos fazer um levantamento dos documentos informativos, interpretativos e opinativos na redação oficial. Eis os mais utilizados:

Documentos Informativos:

O aviso. O contrato. Os atos normativos.

\section{Documentos Interpretativos:}

A exposição de motivos. O regulamento. A ata.

Documentos Opinativos:

A mensagem. O parecer. $\mathrm{O}$ atestado.

Documentos Mistos:

Atos de correspondência (carta, memorando, ofício, telegrama). $O$ relatório.

A própria estrutura desses documentos permite distinguir o fim a que se destinam. Observe-se como os documentos informativos estão mais vinculados com a área da notícia. A autoridade transmite uma informação ou informações. Quando não autoridade, também o signatário presta uma informaçăo, ora como parte contratante, ora como requerente. Nos documentos interpretativos percebe-se a 
notícia numa dimensão mais ampla: as informações mais esclarecedoras, assemelham-se a uma reportagem. Típico exemplo: a Ata, registro circunstanciado do que ocorreu numa reunião. O próprio Regulamento encerra uma série de normas previsiveis na hipótese de que tais fatos venham a ocorrer. Ainda que nele figure um rol de hipóteses, haja vista o Regulamento de Trânsito, pode-se reconstituir todo um esquema de comportamento individual e social em torno do que é ou não infração, nos termos da legislação em vigor.

Nos documentos opinativos, a Autoridade reponta falando mais alto, sublinhando seu pensamento tipicamente editorial numa Mensagem, num Parecer administrativo ou legislativo, numa Resolução com timbre decisório.

Por fim, os documentos mistos em que há trânsito livre para a informação, a interpretação e a opinião, em maior ou menor grandeza, a depender do conteúdo, ou melhor, do tema que determina a importância do documento.

\section{$-00000-$}

Vejamos, numa visualização do te$\mathrm{ma}$, o que sejam alguns documentos oficiais à luz do que estamos expondo.

O Presidente da Comissão de Licitação do Governo do Distrito Federal autorizou a publicação do seguinte Aviso (referimo-nos ao Aviso não ministerial, idêntico ao ofício):

"Informamos aos interessados que às 16 (dezesseis) horas dos dias 09 e 10 de julho do ano em curso, estará reunida a Comissão de Licitação da Secretaria de Administração, a fim de receber propostas para alienação de material considerado inservível pelo Governo do Distrito Federal, conforme Editais de Concorrências n. ${ }^{\circ} \mathrm{s} 01 \mathrm{e}$ 02/70-AL-SEA.

Informações na Divisão do Material ou pelos telefones $42-0333$ e 42-3733.

Brasilia, 09 de julho de 1970

José Geraldo de Lana Torres

Presidente da Comissão de Licitação." 35

Estruturalmente, estamos diante da informação de uma concorrência, com data e hora marcadas para receber as propostas dos interessados. Os principais elementos da noticia aí se encontram:

Que - reunião da Comissão de Licitação da Secretaria da Administração do Governo do Distrito Federal;

Quem - a autoridade autora da convocação;

Quando - nos dias 9 e 10 de julho, às 16 horas;

Onde - na sede da Secretaria da Administração.

Para maiores detalhes - que permitiriam o desenvolvimento da noticia, a propósito da concorrência - a Autoridade informa os números dos telefones da Divisão do Material. Em suma, o fato está informado, atendendo, as 
sim, à finalidade do Aviso dessa natureza: "É uma cientificação, uma noticia, uma ordem", esclarece o Sr. Odacir Beltrão. 36 No caso, uma cientificação.

Tomemos agora o modelo de Oficio inserido no volume de Normas sobre Correspondência e Atos Oticiais, 37 no qual o Diretor do Serviço de Administração do DASP se dirige ao Secretário da Presidência do Tribunal de Contas da União. Vejamos o contexto:

"Em atenção ao solicitado no Ofício n. $1145 / 68$, de 15 de maio último, dessa procedência, apraz-me transmitir a V.Sa. 0 anexo processo (N. ${ }^{\circ}$ DASP $1236-68$ ), pelo qual se verifica haverem sido tomadas por este Departamento, todas as providências previstas em lei, para cuja exata observância baixou esse Egrégio Tribunal instrufões, através do Ofício-cirçular n. ${ }^{\circ}$ $1239 / 65$.

2. As medidas adotadas por este órgão do pessoal encontram-se em plena consonância com as normas ditadas Por essa Corte, convindo transcrever o seguinte trecho da Portaria n. ${ }^{\circ} 38$, de 17 de abril próximo passado, deste Serviço:

"3. Em todos os processos que dependam de registro prévio no Tribunal de Contas, deverão os órgãos componentes deste Departamento enviar, dentro do prazo previsto em lei, os demonstrativos de despesas efetuadas nos três exercícios imediatamente anteriores".
Aproveito a oportunidade para renovar (ou "apresentar", se for a primeira vez) a V.Sa. meus protestos de elevada consideração.

Fulano de Tal

Diretor"

\section{$-00000-$}

Neste documento misto, verifica-se a informação, no $1 .^{\circ}$ parágrafo e a inclusão de elementos de interpretação no $2 .^{\circ}$ parágrafo. Informação: o DASP tomou as providências previstas em lei com referência ao processo $n .{ }^{\circ}$ $1236 / 68$. Interpretação: tanto assim que baixou a Portaria $n .^{\circ} 38$ explicitando as recomendações do Tribunal de Contas.

Observe-se, porém, que a exata compreensão do fato só ocorre ao leitor após a transcrição de trecho da Portaria n. ${ }^{\circ}$ 38. Nos termos dessa Portaria é que o processo n. ${ }^{\circ}$ DASP $1236-68$ foi devidamente examinado.

Jornalisticamente o ofício em si mesmo não poderá transformar-se em noticia sem que se tenha conhecimento pormenorizado do Processo n. ${ }^{\circ}$ DASP $1236-68$ referido no $1 .^{\circ}$ parágrafo. Mas não resta a menor dúvida de que informação e interpretação participam da estrutura deste documento misto.

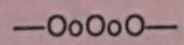

Na Exposição de Motivos - dirigida pelos Ministros de Estado ao Presidente da República - expõem-se as razões que justificam providências administrativas consubstanciadas em forma 
de projetos. Sem dúvida que está implícita uma opinião, haja vista o fato de tais medidas serem sugeridas. Mas, do ponto de vista formal, a estrutura da Exposição de Motivos se assemelha a uma reportagem pormenorizada, respondendo ao por que? das sugestōes que poderão, com o assentimento do Presidente da República, transformarse em lei.

Examinemos a estrutura da Exposição de Motivos encaminhada pelo Ministro da Fazenda, Sr. Antônio Delfim Netto, acompanhada do texto do Decreto-lei $n .0^{\circ} 116$, de 27 de julho de 1970 , alterando legislação fazendária (38):

\section{"EXPOSIÇÃO DE MOTIVOS 281/70, DO MINISTÉRIO DA FAZENDA}

\section{Em 22 de julho de 1970}

\section{Excelentíssimo Senhor Presidente da} Repúbilca:

Objetivando resguardar a economia popular, inadvertidamente aplicada no mercado clandestino de títulos, e considerando a necessidade de impedir que a regularização de emissões Hegais de títulos pudesse ensejar danos à Fazenda Nacional e ao mercado de capitais, mediante a prática de sonegação e crimes contra a economia popular, foi editado o Decreto-lei número 697, de 23 de julho de 1969.

2. A partir de entăo procurou-se implantar as medidas necessárias ao definitivo saneamento da área, através de ação direta do Governo junto às fontes responsáveis até que se chegasse ao termo ideal, equilibrado $e$ racional de solução.

3. O instrumento legal citado propiciou condições de alcance dos objetivos imediatos a que visava, anteparo que tem sido da ação desenvolvida até este momento, cujo êxito compensa sobremodo os esforços despendidos.

4. Atingido o estágio final em que credores e devedores já não sobrepõem óbices à forma de liquidação encaminhada por este Ministério, restanos complementar o diploma de lei em questão para acobertamento jurídico do mecanismo de composição ajustado.

5. Este o motivo por que me permito, respeitosamente, apresentar a Vossa Excelência o projeto de Decretolei em anexo, que resguarda de implicações fiscais os atos de regularização já autorizados e em fase de execução.

6. O artigo $5 .^{\circ}$ introduzido no Decreto-lei $n .^{\circ} 697$, de 23 de julho de 1969 , declara isentas de imposto de renda e de penalidades fiscais as importâncias recebidas em resgate dos títulos desde que tenham sido registrados na forma do Decreto-lei número 286, de $8 T$ de fevereiro de 1967 e $^{\circ}$ mecanismo de liquidação tenha sido aprovado pelo Banco Central do Brasil.

7. No parágrafo $10^{\circ}$ estende-se a aplicação do caput às debêntures que tenham sido emitidas até 1967 para operação de liquidação por transação aprovada pelo Banco Central do Brasil, referidas no artigo $2 .^{\circ}$ do mesmo Decreto-lei. 
8. O parágrafo $2 .^{\circ}$ autoriza as empresas emitentes a contabilizar como despesa operacional a liquidação realizada, até o montante das quantias efetivamente despendidas.

9. No parágrafo $3 .^{\circ}$ faz-se com que a extinção de punibildade já instituída pelo art. 3.० estenda seus efeitos de modo a englobar os atos de preparação, emissão e aplicação dos produtos dos títulos aos quais assegura-se isenção de imposto de renda e penalidades.

10. $04 .^{\circ}$ e último parágrafo destinase a eximir de ação fiscal as operações previstas no artigo, ao mesmo tempo em que propicia o arquivamento de procedimentos fiscais porventura existentes.

11. Finalmente, o conjunto de preceitos se destina a afastar a hipótese de que interpretações outras, sobre a matéria tributária envolvida, venha a pôr em risco a consecução dos objetivos colimados.

Submetendo o junto projeto à elevada consideração de Vossa Excelência - faço com o renovar de minha profunda admiração e respeito.

Antônio Delfim Netto, Ministro da Fazenda."

Trata-se de um texto interpretativo, a partir mesmo do $10^{\circ}$ parágrafo. 0 Ministro faz remissão a uma legislacăo anterior quando se procurou resguardar o mercado de títulos. Outras Providências, porém, foram tomadas com a mesma finalidade $\left(2 .^{\circ}\right.$ parágra- fo). A legislação preencheu os objetivos ( $3 .^{\circ}$ parágrafo). E porque se encontra o problema em seu "estágio final" a autoridade fazendária considerou oportuno complementar a legislação anterior ( $4 .^{\circ}$ parágrafo), apresentando o projeto de Decreto-lei anexo (5..$^{\circ}$ parágrafo).

Do $6 .^{\circ}$ ao $100^{\circ}$ parágrafo, a autoridade fazendária "traduz" o corpo do projeto de Decreto-lei, numa linguagem menos técnica, diriamos mesmo, mais comunicativa. Por fim, no parágrafo 11 , está a afirmação de que esses elementos interpretativos da Exposição de Motivos resguardam outras versōes que possam surgir em prejuizo das providências tomadas.

\section{0}

\section{REFORMAS E TENTATIVAS}

Aproximamo-nos do objetivo de nosso trabalho: sugerir um estudo mais profundo da redação oficial, incluindoa dentro da área da Comunicação: que se procure atualizar certos aspectos informativos, interpretativos e mesmo opinativos, dando-Ihe uma linguagem mais objetiva, mais direta.

Sabemos que o fato, o acontecimento, seja ou não administrativo, repousa numa evidência real: a sua própria existência. Parte-se de um pressuposto inarredável: informa-se, interpretase ou opina-se sobre uma realidade. $E$ os fatos administrativos, que por sua vez determinam atos administrativos, para lembrarmos a clássica distinção, assemelham-se também aos fatos do quotidiano que se transformam em atos 
- as chamadas matérias da comunicação Jornalística. Há, portanto, uma correspondência, uma relação, do ponto de vista da Comunicação, entre um ofício e uma notícia; entre uma ata e uma reportagem; entre um parecer (que deverá ser conclusivo) e um editorial.

Portanto, o problema da Comunicação existe na redação oficial. Necessária, porém, torná-la mais liberta de uns tantos adminiculos que atuam em desfavor da informação breve da interpretação objetiva e da opinião precisa.

\section{A rotina}

Que dizem os autores especializados sobre a linguagem esteriotipada da redação oficial?

Valho-me do Sr. Odacir Beltrão que, logo no terceiro parágrafo da primeira parte de seu livro já citado, ao procurar estabelecer novos agrupamentos da correspondência, opina: "Estabeleçamos novos agrupamentos, enquadrando melhor a carta familiar e conquistando um lugar nos dicionários para a composição epistolar, porque, se o soneto anda em cárcere de aço, o ofício tem seu molde de ferro" (39).

Essas metáforas carcerárias revelam no intimo uma tendência para reivindicar, em favor da redação epistolar, maior liberdade no estilo. E não perdemos por esperar. Mais cedo que pensamos, o Sr. Odacir Beltrão mergulha - leitor no debate sobre a correspondência: técnica ou arte? $E$, através de citações de vários autores, põe-nos a par de certos problemas, inclusive aquele por que se empenham tantos chefes de gabinete e de escritório, quando procuram um correspondente de "redação própria".

Para o Sr. Luís Mercanti, citado pelo Sr. Odacir Beltrão, "há uma arte epistolar, arte que talvez, na maioria dos casos e devido à natureza mesma da função, antes de tudo comunicativa, contenha uma formalidade artística sem buscar, em intenção, tal concepção" (40). (Um pouco indefinido este conceito, em sua parte final, reconheçamos, mas continuemos).

De uma publicação paulista editada pelo SENAC, de São Paulo, outra citação: O redator "deve sentir tudo quanto escreve, mais do que lançar, ao papel, expressões decoradas; mesmo porque, acima de sua função meramente redatorial, há que existir seu espirito de iniciativa e criação, capaz de levá-lo a atender, sempre, que sua tarefa é mais do que rotina: é também uma arte" (41). Mais ainda, citando N.D. Lafuerza, que aconselha: "Năo copie os exemplos de cartas; use $O$ próprio estilo e encare cada problema inteligente e sagazmente. Quando receber uma carta interessante, bem escrita e que o impressione, estude-a, analise-a e valha-se dela para melhorar seu estilo e forma de expressarse" (42).

Como vemos, esses autores cujas opiniōes são abonadas pelo $\mathrm{Sr}$. Odacir Beltrão, insistem num ponto importante: sair da cópia, ou seja, da rotina. Criar, apesar do molde de ferro, embora, queiramos ou não, qualquer gếnero literário possui suas normas ex- 
trínsecas ou intrínsecas. As primeiras são os moldes, as formas, as estruturas; as segundas pertencem mais à individualidade do autor. Basta exemplificar: sob idêntica pressão estrutural, o romance de concepção memorialista de José Lins do Rego não se assemelha ao romance também memorialista de Ciro dos Anjos. Embora obedientes à estrutura do gênero, diferem e muito em concepção: a urdidura da narrativa os distingue nitidamente. São dois autores escrevendo distintamente sob a mesma influência técnica: a memória. Mais: no próprio cárcere de aço do soneto há obras-primas não superadas pela poética liberta dos preceitos técnicos.

Três depoimentos

Ora, no próprio molde de ferro do oficio, e, por extensão da correspondência administrativa, molde de ferro que deve ser mantido em seu aspecto exterior, de acordo com as normas técnicas em que se incluem o vocativo, a introdução, o desenvolvimento, o fecho $\theta$ as recomendações datilográficas, há possibilidades de tornar prática a recomendação de quantos discorrem sobre o assunto: saia da rotina, dê sua contribuição pessoal.

Năo creio que Michel de Montaigne, tå̃o cioso de sua confessional prosa diária no torreão de seu castelo, em Périgond, preparando os Ensaios, tenha sugerido, oficialmente, alguma alteraÇão. Mas se não sugeriu, pensou em sugerir. Pois basta abrir nos Ensaios - Capitulo 13 do Livro III, Da Experiêncla, para sentir até onde ia o cronista de estilo dos mais preciosos, em con- traste com a linguagem rebarbativa dos documentos jurídicos.

Assim escrevia: "Por que nossa linguagem comum, tão cômoda e fácil, se torna obscura e ininteligivel quando empregada em contratos e testamentos? Por que os que se exprimem tão claramente quando falam ou escrevem não acham jeito de não se confundir ou se contradizer em atos desse gênero? É porque os príncipes dessa arte se aplicam com especial cuidado em escolher vocábulos solenes, frases artisticamente construidas, e tanto pesam cada silaba, sutilizam cada termo, que nos embaraçam e embrulham na multiplicidade das fórmuals e das minúcias; e não mais distinguimos regras ou prescriçōes e não entendemos absolutamente mais nada". Conclui citando Sêneca: "Tudo o que se divide até se reduzir a pó, faz-se confuso". 43

Saltemos, porém, de Montaigne para a nossa realidade e vamos encontrar uma curiosa experiência de quem, desejando mexer na redação oficial, terminou por desistir. Sentiu na própria carne o absurdo de tão ousada iniciativa e, motu proprio, reintegrou-se à rotina.

Refiro-me a Medeiros e Albuquerque que, como todo escritor que se preza, tinha horror zoológico aos clichês. Quando diretor do Ministério do Interior, nos primeiros meses da República (era Ministro, Aristides Lobo), Medeiros e Albuquerque sentiu a tentaçāo de querer mudar o estilo administrativo da época. A esse respeito, há em sua obra póstuma Quando Eu Era Vivo (44). este relato que vale a pena Jembrar: 
"Remy de Gourmont escreveu não sei onde um trabalho sobre as pessoas que pensam por "chapas", por frases feitas. Há muitas assim. Ninguém as ouve falar alguns minutos sem que desfechem alguns veneráveis chavões consagrados.

No tempo do Império, o chamado estilo oficial era característico. Em regra, um ofício ou aviso devia apenas ter um período. Esse período podia se estender por páginas e páginas, tendo a cada passo um ponto e vírgula, mas o Ideal era que não quebrasse a sua unidade. Se $O$ ato constituia resposta a outro (Acusando recebido o ofício de V.Exa. de tal data...), passava-se ao meticuloso resumo da peça, aduziamse então considerações pró ou contra a idéia, citações de leis, tudo o que era necessário - e só no fim a autoridade exprimia enfim a sua decisão.

As vezes, esse processo de redação dava lugar a periodos formidáveis. Foi - que sucedeu com um Aviso circular expedido pelo Ministério do Império, poucos dias antes da proclamação da República. Estava tão bem redigido que todos os diretores de estabelecimentos oficiais de ensino a quem se dirigia vieram pessoalmente ao Ministério perguntar o que ele queria dizer...

Lembranda-me disso, eu pensei, quando diretor, em alterar esse estilo. Disse aos rapazes da Diretoria, que todos tinham sido meus colegas e eram meus amigos, qual o meu desejo.

- Mas, como? - inquiriram eles sem saber o que fizessem.
Decidi então que não aceitaria nenhum aviso ou oficio em que houvesse períodos de mais de cinco linhas. Era um processo mécânico e brutal; mas simples, claro, objetivo.

Infelizmente tive de revogar a ordem menos de uma semana depois. A minha diretoria que dava todos os dias quarenta, cinquenta e mais atos a assinar, passou a dar um número irrisório. Por que? Porque o funcionalismo estava habituado a redigir com os velhos chavões tradicionais. Praticamente no miolo daquela gente o que havia eram as chapas impressas com meia dúzia de espaços em branco, onde se punham as frases próprias para cada hipótese.

Se a ordem tivesse durado um ano ou mais, ter-se-iam criado novos estoques de chapas curtas, em poucas linhas. E a mecanização do trabalho se instituiria sobre novas bases. Mas não havia tempo para estabelecer essa outra ordem de cousas".

\section{Outras tentativas}

Houve outras tentativas. Mas, porque seus autores não tivessem na época maior influência no mundo oficial ou porque se utilizassem do nome literário como pedra de toque para exercicios de composição, os exemplos ainda hoje citados são apreciados como curiosidade, sem maiores conseqüências.

Não há quem desconheça hoje os dois relatórios de Graciliano Ramos, da época em que era Prefeito de Palmeira dos índios (1928 e 1929), ende- 
reçados ao Governador Álvaro Paes, de Alagoas. Em trabalho recentemente publicado na Revista do Serviço Público, seu autor, ao defender a tese da impessoalidade na redação oficial, ocupou-se desses relatórios do grande romancista alagoano. (45)

Também o poeta Manuel Bandeira, angustiado com um pátio mal cheiroso nos fundos do apartamento em que morava, na Esplanada do Castelo, publicou uma petição em versos, no Jornal do Brasil, dirigida ao Prefeito do antigo Distrito Federal (Rio de Janeiro), o então General Mendes de Morais. Conseguiu ser atendido na mesma semana. Eis o texto do poema-requerimento, Petição ao Prefeito (46):

"Governador desta cidade, General Mendes de Morais, Ouça o que digo, e tenho que há de Mover-se-lhe o sensivel peito

Dado às coisas municipais!

Há no interior do quarteirão Formado pelas avenidas Antônio Carlos, Beira-Mar, Wilson e Calógeras, tão Bem traçadas e bem construídas, Um pântano que é de amargar!

Não suponha que eu exagero, Excelência: é a verdade pura, Sem nenhum véu de fantasia. Já o pintei uma vez: não quero Fabricar mais literatura Sobre tamanha porcaria!

Reporters, a quem nada escapa, Escreveram sueltos diversos Sobre esse foco de infecção.
Fotógrafos bateram chapa... Coisas melhores que os meus versoś De velho poeta solteirão!

Fiz, por sanear-se esta marema, Uma carta desesperada

Ao seu ilustre antecessor.

Uma carta em forma de poema:

O homem saiu sem fazer nada...

Pelo martírio do Senhor,

Ponha o pátio, insigne Prefeito, Limpo como o olhar da inocência, Limpo como - feita a ressalva Da muita atenção e respeito Devidos a Vossa Excelência Sua excelentíssima calva!"

A literatura epigramática está cheia de exemplos semelhantes. Servindo-se das formas epistolares, os poetas se dirigiam às autoridades e reivindicavam - que thes parecia oportuno, com engenho e arte. Vale a pena observar que estes expedientes têm dado resultado. Seja pela sua forma estética; seja pela revelação da sagacidade do peticionário ou seu valor intelectual; seja pelo prestígio da autoridade em reconhecer os méritos do peticionário um tanto fora da linguagem protocolar e burocrática.

Certa vez prenderam Gregório de Matos. Episódio um tanto confuso, porque, diz o poeta que foi injustiçado, enquanto o verdadeiro ladrão fora ou ficara solto. Ambos - Gregório de Matos e certamente outro companheiro de boemia - se envolveram no roubo (diriamos hoje seqüestro) de uma negra, talvez uma escrava. Confessandose inocente, Gregório de Matos requer sua liberdade ao Desembargador Bel- 
chior da Cunha Brochado, com este soneto (47):

"Senhor Doutor: muito bem-vinda

A esta mofina, e misera cidade Sua justiça agora, e eqüidade, e Letras, com que a todos causa

inveja.

Seja muito bem-vindo: porque veja O maior desbarate, e iniqüidade, Que se tem feito em uma, e outra idade

Desde que há tribunais, e quem os reja.

Que me há de suceder nestas

Montanhas

Com um Ministro em Leis tão pouco

Como previsto em trampas, e visto,

maranhas?

É Ministro de império, mero, e misto, Tão Pilatos no corpo, e nas

entranhas,

Que solta um Barrabás, e prende um

Cristo."

Ainda que se possa admitir que, no fundo, esses poemas burocráticos revelam certa semostração de seus autores, não resta dúvida de que são tentativas inconscientes, talvez, de alterar a expressividade do estilo administrativo. A escolha do verso, por si mesma, indica uma transgressão aos cânones usuais. Mas reflete uma certeza interior de seus autores, de que a Autoridade, longe de af astar o documento por espúrio e contrário às normas técnicas, geralmente o acolhe. $\mathrm{Na}$ verdade, a decisão da Autoridade, nestes casos, é tomada ex officio. 0 poema-requerimento não recebe número nem pasta especial, à maneira de processo: transforma-se num curioso documento que depois se incorpora às obras completas. É o caso da Petição ao Prefeito, de Bandeira, e Soneto, de Gregório de Matos.

\section{Sobre os "bilhetes"}

Mesmo no mundo oficjal as tentativas são feitas com freqüência, embora nem sempre alcancem repercussão, salvo quando se trata de pessoas que exerceram a mais alta função pública do País.

Os "bilhetes" do Sr. Jânio Quadros, quando Presidente da República, eram um expediente prático de transmitir ordens, sugestões, e que se transformaram em notícia por força das características pessoais em que eram redigidos. Mas essas recomendações não representaram nenhuma novidade, salvo sua publicação diária. Não há governante que não tenha em sua mesa um bloco de notas para redigir recomendações, a seus auxiliares mais qualificados, lembrando-Ihes isto e aquilo. Nenhum governante se fecha na sua torre de marfim e se torna incomunicável. E se formos pesquisar os papéis presidenciais encontraremos tantas coleções de bilhetes, quantos foram os chefes de Estado.

Getúlio Vargas também redigia bithetes e nunca thes deu publicidade. Bilhetes dirigidos a Lourival Fontes, Chefe da Casa Civil na última fase de seu governo, reunidos em A Face Final de Vargas (Os bilhetes de Getúlio), pu- 
blicados em reportagem na revista $O$ Cruzeiro e transformados em livro. "Aqueles bilhetes - diz o repórter Glauco Carneiro - ao contrário dos que seriam, depois, institucionalizados por Jânio Quadros, não haviam sido feitos visando à publicidade." Seu estilo era o do lembrete coloquial, como este, a propósito da seca no Nordeste:

"E preciso falar ao Ministro da ViaÇão sabendo como vão os serviços das secas do Norte; se está faltando verba, e se há algum pedido de crédito e onde se acha. Há grande falta de farinha e existe um regular estoque em Santa Catarina, Imbituba, que está se deteriorando. Saber da Comissão de Abastecimento do Nordeste que providências está tomando, quem está substituindo o Cabello nesta comissão etc." (48).

Atento às normas da correspondência oficial, Vargas certa vez recebeu uma carta sem pé nem cabeça. Não jogou na cesta. Encaminhou-a a Lourival Fontes com este bilhete:

"Recebi essa carta meio enigmática ou meio maluca, em três envelopes. Não sei do que se trata, nem pretendo receber. Procura saber quem é e de que se trata." (49).

$\mathrm{Na}$ época do gravador e da fita maGnética, essas recomendações já se tornaram usuais. $\mathrm{Na}$ verdade, o bilhete năo chegou a ser institucionalizado, Porque sempre existiu e continuará a existir.

\section{o dedo do gigante}

Uma ressalva, porém, antes de prosseguirmos. Nossa intenção é modesta.
Nasceu da observação de que, embora no Serviço Público muita rotina venha sofrendo substanciais alterações, haja vista o que se passa nos planos da Documentação e da Informática, em decorrência da necessidade de se aperfeiçoarem os métodos de trabalho na Administração, tornando-os mais afins com a racionalização metodológica, poucos se têm preocupado com a redação oficial, salvo no que se refere à padronização dos documentos. Os livros especializados situam a redação numa ordem mais gramatical que estilistica; e recomendam aos que nela se especializam não se descuidarem do aprendizado da língua.

Conselhos visando a uma melhor redaçāo - objetiva, direta, sem perifrases, clara, etc. - se aplicam não só a quem procure aprender a redigir cartas, ofícios, telegramas, como, de resto, a quem pretende escrever qualquer coisa, mesmo um simples bilhete. Pois até nesses discretos ou indiscretos instrumentos de comunicação revela-se o dedo gigante. Veja-se o telegrama de Rui Barbosa, quando Ministro da Fazenda, endereçado à embaixada do Brasil em Londres:

"Bancos não têm razão nenhuma. Pelos seus estatutos aprovados Governo Brasileiro, eles se obrigaram obedecer leis e regulamentos existentes, ou que de futuro se decretassem. Não Ihes faltarăo advogados para Ihes dar outro parecer, porque os há para tudo; mas a verdade jurídica é esta. Governo Provisório não pensa hostilizar bancos estrangeiros, mas năo thes pode consentir posição privilegiada de, sem capitais no país, viverem de especula- 
ções constantes sobre o câmbio como agora estão fazendo, em prejuizo do comércio, do tesouro e do crédito nacional. Se quiserem fechar não nos fazem falta." (50).

00000

\section{REDAÇÃO E PSICOLOGIA SOCIAL}

A conseqüência de uma legislação específica sobre a redação oficial tem conduzido muita gente a pensar que o essencial é decorar as fórmulas e os formulários. Certo, há fórmulas das quais não se pode fugir. $O$ vocativo é uma fórmula. O próprio endereço, outra fórmula. Mas há fórmulas e fórmulas. E aqui nos encontramos no ponto essencial do problema, no heart of the matter, a exigir meditação e análise.

Em principio, não é a norma técnica que merece reparos. Pacífica a necessidade de se padronizar a feição gráfica e nesse ponto há unanimidade de vistas. Integra-se o material da correspondência nas normas de racionalizaçắo: os modelos de telegramas, cartas e oficios; a qualidade do papel original e cópia; as margens; as distâncias do texto e sua colocação na página. Na própria imprensa - e principalmente na imprensa - a paginação e diagramação são irmãs siamesas de uma estética-formalista, gráfica, sem - que as matérias compostas se acotovelariam e a ninguém seria possivel ler um jornal. Abra-se um livro: ali estão devidamente demarcadas a lombada, os títulos, as espécies de composição, os locais exatos em que devam figurar os nomes do autor, da edi- tora, do tradutor, etc. Impossivel fugir desse formalismo gráfico, uma arte com seus domínios específicos. E assim acontece à redação oficial, de tal modo compreensivel, que, ao apresentar o anteprojeto a respeito das Normas sobre Correspondência e Atos Oficiais, o autor assinalou que as atividades-fins do próprio DASP "estão na dependência direta do funcionamento pleno e igualmente eficiente do sistema integrado das atividades-meios, as quais devem rigorosamente obedecer a princípios e normas de racionalização já comprovados" (51). A norma técnica é imprescindivel.

\section{Uma lição de Tarde}

$O$ que, então, merece reparos? Exatamente o que conduz ao lado oposto da redação própria, isto é, as fórmulas que, de tanto usadas, perdem sua caracteristica, sua grandeza e se reduzem a chavões.

Quando examinamos a questăo do tratamento epistolar, percebemos logo que há uma relação entre o formalismo gráfico e oral e a personalidade. Não é tão simples como parece compreender o porque de certas distinções no mundo oficial e năo oficial, este na fai$x a$ das categorias profissionais quando sabemos que se dá extraordinária importância ao cargo e não se confere a mesma importância ao indivíduo. 0 sabe com quem está falando?, com que certas pessoas costumam pontuar uma discussão com um desconhecido, tão freqüente e tăo revelador na psicologia individual, denuncia vigorosamente um traço forte na psicologia social de uma mentalidade que é especifica- 
mente humana. Independente de quaisquer traços culturais de quantos povos existam na face da terra, o sabe com quem está falando vincula-se à natureza interior do homem em sua interação como ser. No fundo, cada um de nós gostaria que nosso interlocutor soubesse mesmo com quem está falando. Năo importam, no caso, as exegeses de quantos estudiosos do comportamento humano concordam ou não com o autor do Eclesiastes, o Rei Salomão, que também tinha seus titulos de poder e glória, e considerava que tudo no mundo "é vaidade e vento que passa".

Embora sendo "vaidade e vento que passa", somos humanos, possuímos uma visão temporal que nos prende por todos os sentidos: disputam-se cargos, honrarias e, para que esses cargos e honrarias reflitam um status, disputam-se, também,os tratamentos honoríficos e os primeiros lugares à mesa. E, nessa conquista dos primeiros lugares mais uma vez contrariamos a recomendação evangélica... Na realidade, concordamos em teoria com Salomão a propósito da vaidade, e admitimos a grandeza da mensagem de Cristo. Mas, na prática, por culpa de nossos pés presos à terra, "uma geração passa, outra vem", e o homem continua o mesmo. Conclusão que as próprias ciências do homem - a Sociologia, a Psicologia, a Antropologia - năo contestam. Citando o Prof. Goldenweiser - all the fundamental traits of psychic make-up of man anywhere are present everywhere - o sociólogo Q antropólogo Gilberto Freyre chega a Osta afirmaçăo: "Potencialmente - é - que nos indicam tais pesquisas - o homem primitivo e o homem civilizado ou o homem moderno são o mesmo homem" (52).

O Prof. Arthur Ramos, na Introdução à Psicologia Social destaca a contribuição de Gabriel Tarde no estudo do comportamento humano. Para o sociólogo francês, somente através da Psicologia poderia ser compreendida a Sociologia. E afirmava então o que se tornou truísmo: a sociedade não é mais do que a soma dos indivíduos.

De acordo com a teoria da imitação, Tarde vê na sociedade um conjunto de seres que se imitam. Está na imitatividade "o traço essencial da vida social", através de processos como a sugestão e a simpatia. Resumindo, o Prof. Arthur Ramos acrescenta: "O senhor é imitado pelo escravo, o patrício pelo plebeu, o nobre pelo burguês, o homem das cidades pelo homem dos campos, o pai pelos filhos, o mestre pelos alunos, etc. Nesta hierarquia, examina também Tarde a distância do modelo, distância concebida no seu sentido sociológico. Quanto mais próximo o modelo do superior, maior è a eficiéncia da imitação." Cita, a seguir, trecho da obra de Tarde, Les Lois de l'Imitation: "Esta lei de imitaçăo do mais próximo, do menos distante, explica o caráter sucessivo e gradual da propagação de um exemplo partido do alto de uma sociedade. Como corolário, pode-se induzir disto, quando vemos uma classe inferior se pôr a imitar pela primeira vez uma classe muito superior, que a distância entre as duas diminui" (53).

Compreensivel, portanto, que na correspondência oficial algumas fórmulas 
de início restritas, limitadas a certo circulo social e de expressividade no mundo econômico e político, em decorrência do princípio de imitação, terminassem sendo adotadas por outras classes ou categorias sociais. Observem-se certas expressões, geralmente títulos e patentes, usadas para expressar poder e glória. Ainda hoje, no Nordeste, a patente de coronel tem Iivre curso no sentido de poder político. Lampião era o Capitão Virgulino Ferreira. Vulgarizou-se tanto o titulo de Doutor, que hoje faz parte da linguagem coloquial. E em certas cidades do interior, onde grupos de pessoas idosas se reúnem depois do Jantar, cadeiras nas calçadas, a este grupo se denomina - o Senado. Traços de imitação, todos eles, e bem que mereceria um estudo mais amplo este dos costumes representarem nada mais nada menos que o desejo ora consciente, ora inconsciente, de ser o que está configurado nos títulos e nos brasões. "Uma imitação consciente e refletida, de início, torna-se gradativamente inconsciente e automática. $\mathrm{A} \mathrm{ci-}$ vilização pode determinar o fenômeno inverso: a imitação, de inconsciente o involuntária, torna-se consciente e refletida" (54).

Um documento pioneiro

No caso da correspondência oficial, sem fugir à regra do comportamento humano, exageramos. Um estudo mais amplo de Psicologia Social ou de Sociologia Psicológica (55) em relação aos títulos de nobreza bem que elucidaria esta questăo das distinções honorificas. Mas não é este nosso propósito. Importante é considerar que o tratamento simboliza poder. E como este poder temporal está vinculado a um cargo, a uma função pública ou relacionado com os serviços prestados à comunidade, é razão para estranhar cairmos no emprego do superlativo como última expressão vernácula significando o mais alto grau. E, por imitação, continuamos a distribuir, indistintamente, por simpatia ou condescendência, os excelentissimos, os ilustrissimos, os reverendissimos em qualquer escalão.

Quando vemos hoje que a troca de um Vossa Excelência por Vossa Senhoria pode resultar, no máximo, num episódio burocrático sem maiores conseqüências, em que uma das auxiliares do Gabinete corre o risco de ser chamada a atenção pela chefia, sequer imaginamos que certas infraçōes às normas técnicas da redação oficial podiam terminar com degredo na África.

Felipe I de Portugal e II da Espanha, em face das "grandes desordens $e$ abusos, que se tem introduzido no modo de falar e escrever, que continuadamente em crescimento, e tem chegado a muito excesso, de que tem resultado muitos inconvenientes, e que conviria muito a meu serviço, e ao bem e socego dos meus Vassalos 0 reformar os Estylos de falar e escrever, e reduzi-los a ordem e termo certo; e praticando-o e tratando-o com pessoas do meu Conselho, e outras de Letras $e$ de experiência, ordenei de prover nisto na forma e maneira ao diante decla. rada", baixou o Alvará de 16 de setembro de 1597.

E um documento pioneiro. "Foi, sem dúvida, uma medida de racionalizaçăo, 
útil ao bom andamento dos documentos de valor administrativo", comentou o Prof. João Alfredo Libânio Guedes (56).

Do ponto de vista técnico, a própria ementa é elucidativa: "Em que se determinarão os Tratamentos, que se devem dar por palavra e por escripto nestes Reinos e Senhorios". O legislador, no caso o próprio El Rei, não só se refere à linguagem escrita, à expressão escrita, mas subordina às determinações do Alvará a expressão oral.

Embora desculpando-se por legislar em causa própria, El Rei Filipe não parecia inclinar-se para a linguagem prolixa. Tanto que, na correspondência que the fosse remetida, o que hoje denominamos vocativos, Sua Majestade em seu "ordeno e mando", dizia que bastava uma expressão - Senhor. "... no alto das cartas ou papéis que se me escreverem, se ponha Senhor, sem outra cousa, e no fim dellas, Deos guarde a Catholica pessôa de Vossa Magestade". E, quanto à assinatura do remetente, dizia: "e no fim da lauda, em se rematar a carta, se porá o signal de quem a escrever, sem outra cousa alguma".

No rol dos tratamentos recomendados por Sua Majestade Filipe I de Portugal e II da Espanha, deparamos com Excelência e Senhoria. Mas quais os que podiam merecê-lo? Para o rei e a rainha, Majestade; para os príncipes herdeiros, "aos Infantes e às Infantes", Alteza; para os genros e noras, cunhados e cunhadas do rei e da rainha, "se faça o mesmo Tratamento, que aos Infantes"; e só: "que a nenhuma outra pessôa se possa fallar, nem escrever por Alteza."

Aos filhos dos infantes, isto é, dos príncipes, netos do rei e da rainha, "se ponha no alto da carta Senhor, e no sobrescripto, ao Senhor, Dom N., ou à Senhora Dona N., e se the escreva e falle por Excellencia".

Havia, porém, uma exceção. Certamente, tão embaralhada estava a terminologia da época, que outras pessoas, de mais aproximado convívio real, eram tratadas por Excelência. Não era um tratamento de direito, mas de fato. Provavelmente nem tivessem sangue azul. Mas cumpria seguir a tradição. Uma descortesia - e logo descortesia real - cassar-Ihe o título. A fim de superar essa dificuldade, El Rei deu ao item 7 do Alvará esta redação: "Que a nenhuma outra pessôa, por grande Estado, Officio ou Dignidade que tenha, se falle por Excellencia, de palavra, nem por escripto, senão áquellas pessôas, a quem os Senhores feito mercê, que se chacem e fallem por Excellência, como êlles, e eu temos feito ao Duque de Bragança; nem se fallará assim mesmo, nem escreverá a nenhuma pessôa por Senhoria Illustrissa nem: ao Arcebispo de Reverendissima Braga, como a Primaz, se poderá fallar e escrever por Senhoria Reverendissima".

Cortando nos superlativos, é de ver que EI Rei năo teve seguidores.

Quanto ao tratamento Senhoria, era exclusivo dos Arcebispos e Bispos, Duques e seus filhos "que eu mandar cubrir", Marqueses e Condes e a Prior 
do Crata, "e não a outra pessoa alguma". Vice-reis e Governadores também mereciam ser tratados por Senhoria, "em quanto servirem os ditos cargos". No exercício de suas funçöes, também mereciam o Senhoria o Regedor da Justiça da Casa da Suplicação, Governador da Relação do Porto, Vedores da Fazenda, Presidentes do Desembargo do Paço, e da "Meza" da Consciência e Ordens. Quando fora dos tribunais, a estas autoridades "se Ihes não poderá fallar, nem escrever por Senhoria". Por fim: igual tratamento aos Embaixadores, aos vice-reis e governadores das índias; e, "a qualquer outra pessôa, que por algum respeito eu mandar cubrir, se possa escrever e fallar por Senhoria". Fora disso, "se não poderá fazer com outra pessôa alguma", asseverava sua Majestade.

Pelo visto, as recomendações eram para valer. Se hoje, as normas burocráticas, desobedecidas, revelam simples falta de atenção ou ignorância da legislação, sem maiores conseqüências, palavra de rei naqueles tempos valia muito. Ou admitia o Rei que muito devia valer. Pois o item 20, final, do Alvará de Sua Majestade é terrível. A pena de pato de Lobo Soares, Secretário real, deve ter estremecido, em face das ameaças que recairiam sobre os súditos de Sua Majestade, quando escreveu:

"20. E os que não cumprirem e guardarem inteiramente em todo, ou em parte o conteúdo nesta minha Lei, incorrerão pela primeira vez em dez mil réis, a metade para o accusador, e outra para Captivos; e pela segunda, em vinte mil réis, repartidos pela dita maneira: $e$ isto as pessôas, que tiverem qualidade de Fidalgos até CavaIheiros; e as outras pessôas de menor qualidade incorrerão em pena de dez cruzados pela primeira vez e hum anno de degredo fora do lugar e termo; e pela segunda, em vinte cruzados e hum anno de degredo para África; e sendo compreendidos mais vezes, serão comndenados em móres penas, segundo 0 arbítrio do Julgador, tendo respeito às qualidades das pessôas culpadas, e à continuação de sua culpa, além do desprazer, que eu por isso receberei, com que mandarei prover no que fôr necessário, que sendo a mór pena de todas, he de crer, que não haverá quem dê occasião a isso".

Quantos infratores teria o Rei Felipe degredado para a África, por transgressão ao seu Alvará? E quais seriam essas "móres penas" não explícitas, embora Sua Majestade (convém se respeite a determinação real) a imaginasse tão violenta que, tinha certeza, não surgiria ninguém que desse "ocasião a isso"? Ainda um esclarecimento histórico: como é antiga a participaçăo nas multas, vê-se pelo que o acusador (o denunciante) iria receber metade do total da multa; a outra metade seria destinada aos cativos - aqui figurando no sentido de presos, detentos comuns, mantidos pela administração pública.

\section{Os fechos}

Mas a cortesia năo fica apenas no tratamento: estende-se ao fecho, também denominado encerramento ou des- 
pedida. E aqui vamos encontrar mais um ponto, em que a repetição desgastou a expressividade e hoje reclama novas maneiras de reverência.

A propósito dos fechos, o Prof. J. R. Whitaker Penteado repele as fórmulas tradicionais e, em seu lugar, defende - final que produza resultados em relação a quem escreve:

"1.9) Levar o leitor a agir - a fazer - que você esperava que ele fizesse.

$\left.2 .^{\circ}\right)$ Deixar boa impressão a seu respeito - caso não fosse ação que se esperava do destinatário". 57

Por que se empenha em alterar as fórmulas tradicionais? Porque, acrescenta o Prof. Penteado, "por serem fórmulas esses parágrafos são inúteis; não são lidos". Realmente, não são lidos. Preferivel a expressão de cortesia de uma, duas palavras, do que a grandiloqüência vazia, sem sentido em muitos casos. Medite-se um pouco sobre alguns fechos, em que estima e distinta, ora na função substantiva (aita estima ou mais alta estima) ora na função adjetiva distinta consideração; em que por vezes se junta o advérbio mui; em que apreçc ora é respeitoso ora é simples, sem adjetivos; em que se utiliza - vocábulo protestos de maneira inadequada, porquanto significando "afirmação solene" ou "designio inabalável", seu efeito é inexpressivo diante de nossas considerações; e percebemos logo a inutilidade do palavrório, por três razões: umà de sentido ético - de repetidas, perderam o viço; a segunda, de sentido racional - não favorece a Administração e resulta em Perda de espaço e tempo; a terceira, de sentido prático - "por serem fórmulas, esses parágrafos são inúteis; não são lidos".

Balzac, tão prolixo e minucioso em seus romances, não dá importância ao fecho, quando Rabourdin, personagem de Os Funcionários, redige a carta de demissão. No lugar do fecho, o romancista escreve: "Seguiam-se as fórmulas de reverência". 58

Mas nem todos o consideravam inútil e perfunctório. Este episódio narrado por Taunay, sob o título Deus e a República, se deve à fórmula de reverência ao Imperador:

"Era o Conselheiro Paulino José Soares de Souza provedor da Santa Casa de Misericórdia, quando foi intimado pelas autoridades republicanas a acabar com o Deus guarde dos seus oficios ao Governo. "Não me é lícito aceder à indicação de V.Exa" - respondeu o Conselheiro ao Ministro do Interior: - Neste estabelecimento ainda há Deus, nem se o pode dispensar no meio de tantos sofrimentos e misérias dos homens". E não acatou a fórmula. 59

\section{Outrossim...}

É, contudo, no corpo do documento - e convém lembrar que estamos tratando do que ocupa, provavelmente, a maior parte da correspondência oficial: o ofício, a carta, o memorando - que a redação oficial oferece possibilidades de maior análise. $\mathrm{Na}$ parte destinada à explanação ou contexto do ofício é que $\circ$ redator tem condições de apresentar o que se exige dele: a "redação própria". 
O Sr. Odacir Beltrão não esconde sua apreensão ao afirmar: "Há termos e expressões sem qualquer proveito prático e fechos extensos demais ou redundantes, quando não contrastam seus elementos". E acrescenta: "O emprego exagerado de fórmulas (para os devidos fins/de ordem superior/chamo a vossa atenção/reportando-me ao seu oficio em referência), os pleonasmos e as incongruências repetidos sem a menor análise, impelem o redator a vícios". 60 Nessa ordem, podem ser consideradas certas expressões invariáveis (contudo, todavia, entretanto, outrossim) com que se iniciam as subordinadas. $\mathrm{Na}$ linguagem oficial, mais que abusivo o uso do advérbio outrossim, com a acepção de também, igualmente, quando se deseja esclarecer aspectos do que se está desenvolvendo: "Outrossim, esclareço a Vossa Excelência..."

\section{Conta Flanklin de Oliveira episódio} ocorrido na redação do Correio da Manhã do Rio de Janeiro. Era Graciliano Ramos responsável pela revisão de originais. "Sua função: pentear os textos - isto que hoje se chama copy-desk. Uma noite, parou na leitura de um original, suspendeu a cabeça, ficou longo tempo parecendo perdido no vácuo. Súbito, rugiu:

- Outrossim... Outrossim é a... (e soltou o palavrão), 61

Pode-se imaginar a indignação do criador de Angústia (Luiz da Silva, personagem principal, é funcionário público) corrigindo um texto Jornalístico provavelmente um suelto, um tópico, um editorial - em que o redator, tal- vez funcionário público, tenha deixado escapulir o outrossim da correspondência oficial. A implicância de Graciliano Ramos não seria tanto em relação ao vocábulo, mas ao seu emprego num texto jornalístico: usar uma palavra já abolida da expressão oral. Pois - é o caso de perguntar - quem hoje em dia, numa conversação, usa por acaso o outrossim?

As perifrases

As perifrases concorrem também para 0 engorduramento da expressão escrita. Se desejamos dizer informo a $V$. Exa., não resistimos à tentação de escrever cumpre-me informar a $V$ Exa. E se nossa intenção é informar que recebemos a carta ou o oficio, criamos este circunlóquio utilizando inclusive um verbo que deixou há muito de circular na expressão oral: Apraz-me acusar o recebimento de.

Muito comum em ofícios uma construção em que no primeiro parágrafo informa-se: Apraz-me acusar o recebimento do oficio..., no qual V.Sa solicita isto e aquilo. E, a seguir, no segundo parágrafo, outra informação que de certo modo não corresponde ao aprazimento exposto no início: Em atenção ao assunto, cumpre-me informar V.Sa. de que não nos é dado o prazer de atender à solicitação, visto que (e segue-se o motivo).

Num caso como este, válida a intenção de Medeiros e Albuquerque: reduzir o ofício a cinco linhas. Mas, ainda que se possa argumentar no sentido de que uma estrutura condensada năo enobrece a redação oficial e, reduzin- 
do o toque de cortesia tornaria pouco simpática a Autoridade (principalmente quando a informação não corresponde ao que deseja o destinatário), mais vale ainda a precisão do que os circunlóquios rebarbativos. No caso, bastaria informar que não se tornou possivel deferir ou atender à solicitação, porquanto contraria as normas tais e tais em vigor. Nada como a letra escrita, a lei, devidamente citada, para dirimir dúvidas. E se se trata de maior exegese, cite-se a jurisprudência, desenvolva-se o corpo do ofício. Argumente-se.

\section{Gordos e Magros}

Falamos em engorduramento da expressão escrita. Na redação oficial, um estilo ático e objetivo é preferivel. Não são as palavras que enriquecem o estilo: são as idéias. Na correspondência oficial, a informação quando se tem alguma coisa a dizer: a interpretação e a opinião, quando se pode argumentar e concluir.

José Lins do Rego dividia os escritores em duas categorias: gordos e magros. Ele preferia os magros, que se caracterizam pelo mínimo de palavias, - máximo de expressão. Dizia que Alencar engordou muito. Nabuco "de vez em quando saía de seu peso normal, mas voltava logo à abstinência que the restituia a performance". Rui era um gordo de estilo. Coelho Neto, "um fraco dos peitos, fazendo todo o possivel para ganhar peso. E consumiu adjetivos com fúria, a tantas gramas por dia".. Entretanto, ao definir - melhor estilo, José Lins do Rego dava a sua receita de cronista e de romancista entre os maiores: "Mas a grandeza não está nestes gordos nem entre os magros por greve de fome. A grandeza está, como a beleza nas muIheres, nas fausses-maigres, no milagre do equilíbrio, na proporção instintiva das formas. Machado de Assis foi destes, mantendo-se toda a vida sem palavras de mais, sem palavras de menos". 62. No estilo oficial, essa gordura, na base de perífrases, reflete em muitos casos idéias magras. Na verdade, o que se deve buscar é a simplicidade de mãos dadas com a objetividade da expressão. La Bruyère costumava recomendar: "Se tu queres dizer que ele chora, dize: chora. Todo mundo compreenderá. 63

\section{Um parecer de Machado de Assis}

A referência a Machado de Assis, que foi burocrata dos quatro costados, ilustra essa precisão do estilo, mesmo na redação oficial. $A$ imagem que $R$. Magalhães Jr. nos dá do criador de Dom Casmurro e de muitos contos burocráticos é de um perfeccionista. Teixeira de Melo, quando diretor da $\mathrm{Bi}$ blioteca Nacional, quis levar Machado de Assis, seu amigo, para exercer as funções de chefe da seção de manuscritos. O escritor recusou. E comenta: "A Biblioteca Nacional poderia ter feito de Machado de Assis um escavador de papéis velhos, um simples alfarrabista. Reagiu e fez bem. Não quer isso dizer que the tivessem sido suaves as tarefas que executou no Ministério. Ele era um homem minucioso, rigorista, cheio de escrúpulos, querendo a perfeição em tudo quanto fazia, ao ponto de rascunhar nove vezes seguidas um ofício, um despacho. 64 
Acredito. Não pelo perfeccionismo, em si mesmo, mas pela busca natural da expressão exata. E, embora obedecesse às normas de apresentação $\theta$ fecho, segundo o figurino da época, Machado de Assis era realmente objetivo. Argumentava através de recursos, hoje pouco utilizado, mas de efeito e realce num parecer: as frases interrogativas, seguidas da opinião do autor.

Em documento hoje incorporado ao Relatório do Ministério da Agricultura, de 1876, há parecer de autoria de Machado de Assis, na qualidade de chefe interino da $2 .^{\text {a }}$ seção da Diretoria da Agricultura. Trata-se da interpretação de dispositivo vinculado à Lei de 28 de setembro de 1871 , conhecida por Lei do Ventre Livre. Porque não fosse bacharel, a linguagem do parecer difere inclusive do estilo bacharelesco. É precisa e enxuta. Basta este parágrafo, ao opinar sobre a Lei do Ventre Livre:

"Cautelosa, equitativa, correta, em relação à propriedade dos senhores, ela (a Lei) não obstante, uma lei de liberdade, cujo interesse ampara em todas as suas partes e disposições. E ocioso apontar o que está no ânimo de quantos a têm folheado; desde o direito e facilidades da alforria até à disposição máxima, sua alma e fundamento, a Lei de 28 de setembro quis, primeiro que tudo, proclamar, promover e resguardar o interesse da liberdade. Sendo este o espírito da lei, é para mim manifesto que num caso como o do Art. 19 do Regulamento, em que, como ficou dito, o objeto superior e essencial é a liberdade do escravo, não podia o legislador consen- tir que esta perecesse sem aplicar em seu favor a preciosa garantia indicada no Art. $7 .^{\circ}$ da Lei. Tal é o meu parecer, que sujeito à esclarecida competência da diretoria. Em 21 de julho de 1876. - Machado de Assis".

Comentando o parecer, R. MagaIhães Jr. acrescenta: "As linhas finais, que podem parecer um sinal de transigência, da parte do primeiro oficial, no exercício interino da chefia da $2 .^{a}$ seção da Diretoria da Agricultura, são apenas uma deferência de funcionário para com o superior hierárquico, de acordo com as praxes burocráticas da época. O parecer é afirmativo, apresentando argumentos válidos, examinandio de frente a questão, alinhando razões outras que não as que já se encontravam nos pareceres anteriores e, além do mais, contestando formalmente as opiniões do diretor Gusmão Lobo". 65

Não só rigorista no rascunhar nove vezes um ofício. Rigorista também no cumprimento das determinações oficiais. Quem conta é R. Magalhães Jr.: "Promovido a diretor nas proximidades do advento da República, afirma-se que Machado resistiu por mero zela funcional à derrubada do retrato do imperador deposto que havia na parede da sala de sua Diretoria. "Aquil entrou com uma portaria e daqui só sairá com outra portaria. - é a frase que the atribuem". 66

\section{A carta de Caminha}

Essa objetividade se encontra nos documentos antigos. E o próprio Rei Filipe, Já citado, não era de outra opi- 
nião: "Que no Estylo de escrever humas pessoas a outras, se guarde geralmente sem excepção alguma a ordem seguinte: Começará a carta, ou papel pela razão, ou pelo negócio, sobre que se escrever, sem pôr debaixo da Cruz no alto, nem ao princípio da regra nenhum título, nem letra, nem cifra, que o signifique". 67

Era praxe, depois do vocativo, começar a carta pelo assunto. Não conseguimos, em nossas pesquisas, descobrir a origem da expressão "escrevothe estas mal traçadas linhas". Creio que no classicismo não foi. Coisas do Romantismo? No período clássico, a prosa era de tal objetividade, no plano da informação e da narrativa, que hoje um modelo de reportagem é a carta de Pero Vaz de Caminha a D. Manuel I. Modelo de reportagem e de relatório.

Caminha, funcionário público, fora nomeado para Calicut, Índia, onde exerceria as funções de escrivão. $\mathrm{Na}$ frota de Cabral, era um passageiro. Mas trazia no sangue a marca do escritor. Não podia deixar passar em branco tantos acontecimentos. $\mathrm{Na}$ opinião do Prof. Silvio Batista Pereira, responsável pela edição do Vocabulário da Carta de Pero Vaz de Caminha, Caminha "era urn excelente narrador e deu-nos das terras de Porto Seguro, onde esteve cerca de dez dias, narração muito curiosa. ... Caminha não deforma a realidade, que retrata com mão segura e hábil, fixando-lhe os asPectos, surpreendendo-lhe peculiaridades, comparando-lhe qualidades. Diz somente o que é preciso dizer. É a Pena de um escritor lúcido, a redigir, com meticulosa precisão, sem carregar nas cores, a notícia da terra que os portugueses acabavam de descobrir, ou melhormente, de achar". 68

Entretanto, como era de praxe na época, depois do vocativo iniciar o tema, Caminha não o fez. $O$ fato se esclarece quando sabemos que ele não era a autoridade oficial para tanto. Mas a comichão para escrever era muito forte. E por isso se justificou de remeter a carta, que assim começa:

"Senhor: / Pôsto que o Capitãomor desta vossa frota, e assim os outros capitães escrevam a Vossa Alteza a nova do achamento desta vossa terra nova, que nesta navegação agora se achou, năo deixarei também de dar minha conta disso a Vossa Alteza, o melhor que eu puder, ainda que - para o bem contar e falar - o saiba fazer pior que todos. / Tome Vossa Aiteza, porém, minha ignorância por boa vontade, e creia bem por certo que, para alindar nem afear, não porei aqui mais do que aquilo que vi e me pareceu. / Da marinhagem e singraduras do caminho não darei aqui conta a Vossa Alteza, porque o não saberei fazer, e os pilotos devem ter esse cuidado. Portanto, Senhor, do que hei-defalar, começo e digo:". 69 Segue-se a narrativa.

Por que escreveu então, se outros havia na viagem, com o objetivo de dar noticias a El Rei? Ainda hoje certos intérpretes não deixam de pespegar na figura de nosso escrivão Pero Vaz de Caminha (que seria hoje doublé de funcionário público e jornalista) a responsabilidade do peditório epistolar. 
No caso, Caminha, cujo genro estava lotado em qualquer função pública na Ilha de São Tomé, pedia a D. Manuel sua remoção para Lisboa. Ontem como hoje as coisas não mudaram: all the fundamental traits of psychic make-up of men anywhere are present everywhere, conceitua o Professor Goldenweiser. E não seria para estranhar, este final magnífico da carta de um pai que desejava uma situação melhor para a filha, se possivel em Lisboa, numa época em que as distâncias no tempo e no espaço eram muito maiores que as de hoje, embora estivessem as armas e os barões assinalados empenhados em dilatar a fé e o Império. Caminha provavelmente pedia o mínimo. $E$ fê-lo com engenho e arte:

"E nesta maneira, Senhor, dou aqui a Vossa Alteza conta do que nesta terra vi. E, se algum pouco me alonguei, Ela me perdoe, pois o desejo que tinha de tudo Vos dizer, mo fez pôr assim pelo miudo. / $\mathrm{E}$ pois que, $\mathrm{Se}-$ nhor, é certo que, assim neste cargo que levo, como em outra qualquer coisa que de vosso serviço for, Vossa Alteza há de ser de mim muito bem servida, a Ela peço que, por me fazer graça especial, mande vir da llha de São Tomé a Jorge de Osório, meu genro - o que dEla receberei em muita mèrcê. / Beijo as mãos de Vossa Alteza. / Deste Pôrto Seguro, da Vossa Ilha de Vera Cruz, hoje, sexta-feira, primeiro dia de maio de 1500. - Pero Vaz de Caminha". 70

\section{Outros documentos}

A recomendação do Rei Fillipe, de se iniciar a carta "pela razão, ou pelo negócio", era costume na época. Basta consultar os documentos dos primeiros anos da descoberta do Brasil para se conhecer o estilo, sem circunlóquios. Vejamos alguns exemplos:

Carta de D. João III a Martim Afonso de Souza, aos 28 de setembro de 1532:

"Martim Afonso, amigo: Eu El-Rei vos envio muito saudar.

$\mathrm{Vi}$ as cartas que me escrevestes por João de Souza; e por ele soube da vossa chegada a essa terra do Brasil, e como feis correndo a costa, caminho do Rio da Prata; e assim do que passastes com as naus francesas, dos corsários que tomastes, e tudo o que nisso fizestes, vos agradeço muito; $e$ foi tão bem feito como se de vós esperava; e sou certo qual a vontade que tendes de me servir". 71

Carta de Duarte Coelho, Donatário de Pernambuco, ao Rei D. João III, em 27 de abril de 1542:

"Senhor - Pelo capitão dos navios que daqui mandei o mês de setembro passado, del conta a V.A. de minha viagem e chegada a esta Nova Luzitánia, e do que era passado, e depois aqui meti-me, senhor, a dar ordem ao sossego e paz da terra com dádivas a uns e com pelas mãos doutros, porque tudo era necessário, e assim del ordem a se fazerem engenhos de açúcares que de lá trouxe contratados, fazendo tudo quanto me requeriam, dando tudo o que me pediram, sem olhar a proveito nem a interesse algum meu, mas a obra ir avante como desejo. Temos grande soma de canas plantadas, todo o povo com todo trabalho 
que foi possível, e dando a todos ajuda que a mim foi possível, e cedo acabaremos um engenho mui grande $e$ perfeito, e ando ordenando de começar outros, praza ao Senhor Deus que segundo sua graça, misericórdia e minha boa intenção, sua ajuda". 72

Carta de Duarte Coelho ao Rei D. João III, em 20 de dezembro de 1546:

"Senhor. - Posto que neste ano de 1546 tenha escrito por três vezes a V.A., dando-lhe conta das coisas de cá $\theta$ assim de algumas coisas que me pareceu seu serviço e pela incerteza das coisas do mar, quis, Senhor, por esta tornar a dar a mesma conta para V.A., prover o que for seu serviço". 73

\section{O tópico frasal}

São documentos esses que ratificam a intenção de quem escreve com o objetivo de comunicar a alguém alguma coisa: esclarecer o que se deseja no tópico trasal e desenvolver em ordem decrescente de importância.

Esclarece o Prof. Othon M. Garcia que, por tópico frasal deve-se entender a idéia núcleo da mensagem. Em Pesquisa feita nos parágrafos de vários escritores, entre livros de ficção e liVros técnicos, o autor de Comunicação em Prosa Moderna encontrou em mais de $60 \%$ deles na estrutura do paráGrafo o tópico frasal. "É provável que tal estrutura - esclarece o Prof. Othon M. Garcia - predominante também em muitas línguas modernas, todas indoouropéias, todas marcadas pela heranSa greco-latina, decorra de um processo de raciocínio dedutivo. De fato, que é o tópico frasal, quando inicial, senão uma generalização a que se seguem as especificações contidas no desenvolvimento? Esse modo de assim expor ou explanar idéias é, em essência, o método dedutivo: do geral para o particular. Quando o tópico frasal vem no fim do parágrafo - e neste caso é, realmente, a sua conclusão precedido pelas especificações, o método é essencialmente indutivo: do particular para o geral". 74

Esta teorização sobre como escrever - que se deseja transmitir termina, de algum modo, caindo no que comumente desprezamos por não vir lastreado em qualquer corpo de doutrina, embora estejam as doutrinas nele fundadas: o bom senso. É paradoxo asseverar isto nenhuma doutrina se projeta no tempo e no espaço, se não for confirmada pela experiência, pela sua aplicação prática, e esta viabilidade confirma o bom senso de quem a sugeriu; entretanto, pouco se comovem, os espíritos afeitos à erudição, se as sugestões, as idéias, inspiradas no bom senso, não vêm acompanhadas de um considerável lastro de teorização.

Extensão do homem, para usarmos a expressão de Marshall MacLuhann, 77 a correspondência tende a acompanhar a evolução humana, sem desviarse de suas linhas estruturais bem definidas. Pretendemos indicar que, a respeito, os compêndios têm-se limitado mais a recomendar a aplicação gramatical e lógica aos textos que situar esse texto dentro de esquema da Comunicação. Se compararmos um jornal do século passado com o Jornal moder- 
no, a distância que os separa se assemelha à que existe entre a idade da pedra polida e a idade contemporânea. Não só no sentido tecnológico aplicado à imprensa, tornando a galáxia de Gutemberg cada vez mais ampla em seus domínios, mas no sentido redatorial. As normas gramaticais e lógicas, estas se devem aplicar, com justeza, a qualquer texto, seja a correspondência, seja a noticia, seja uma página de ficção. Mas a expressividade escrita, esta não deve ficar presa a fórmulas.

Embora nos tenhamos limitado, neste trabalho, ao exame da ccrrespondência epistolar, bem que o estudo da matéria comporta o exame de outros documentos. Caberia à Administração Pública indagar se, com vistas a uma racionalização, na correspondência oficial os textos alcançam o público, ou se a própria estrutura do documento dificulta os subsídios essenciais à clareza, à concisão, à harmonia, à originalidade e ao vigor. Embora o redator posșa conhecer seu ofício e desempenhá-lo com eficiência, a obediência rigorosa às normas existentes não prejudica o texto e até bloqueia a objetividade da mensagem?

Felizmente, as modernas linhas pedagógicas estão conferindo o mais alto valor ao poder criativo da inteligência humana. O que nos leva a citar Goethe, na traduçåo de Augusto Meyer: "Cinzenta, caro amigo, é toda a teoria/E verde é a deliciosa árvore da vida". 75

\section{III - CONCLUSÕES}

Apesar do desenvolvimento dos meios de comunicação social ou de massa, na sociedade contemporânea, a correspondência oficial ou não é 0 instrumento válido nas relações humanas. Ainda é o preto no branco, com a assinatura, o que determina a autenticidade do que se escreve. Hoje como ontem foge-se do que é apócrifo e falso; e, por extensão, do que traz rasuras, apresenta-se truncado ou é ilegivel.

Louis Chaffurin, autor de um manual de correspondência, edição recente, escreveu: "Il semble qu'on écrive de moins en moins. On télégraphie. On téléphone, surtout. On arrive, plus vite que la poste, en automobile ou en avion. La lettre se meurt. / La lettre, cependant, n'est pas encore morte. II y a beaucoup de circonstances où il nous est indispensable de savoir écrire. II faut remercier, compatir, féliciter, offrir des voeux. II faut garder le contact avec les absents. La lettre badine, la lettre qui autrefois était surtourt un jeu d'esprit ou un exercice de style, a presque disparu avec les longs loisirs, et combien est-ce dommage! II reste les lettres les plus difficiles à rédiger, celles où la fantaisie n'a plus de place, où il faut peser chaque mot et suivre rigoureusement les règles de la correction et de la courtoisie". 76

Embora a correspondência seja hoje menos freqüente devido à influência de outros meios de comunicação mais diretos - e aproxima-se a época do vídeo-telefone, do TV-fone ou que outro nome venha a ter o telefone com imagem - percebemos, os que a redigem e os que mantêm com ela permanente convivio, estar, em alguns aspectos, desatualizada. Quando Pero Vaz de 
Caminha, no fecho de sua carta a D. Manuel, expressou, na fórmula, a intenção de beijar as mãos de Sua Alte$z a$, refletia um costume na época. Beija-mão que ainda se impõe como gesto de fidalguia, de reverência, de carinho, de amizade e de atenção. $\mathrm{Na}$ realidade, o escrivão beijaria as mãos de D. Manuel, ao despedir-se, numa audiência. Beija-se ainda hoje o anel do Papa e dos altos prelados da Igreja Católica; cumprimentam-se os povos eslavos e orientais com beijos na face; as muIheres do Ocidente simulam um beijo na face, uma das outras, quando se encontram e se despedem. Mais real e até mais sincero, portanto, o beijamão da época de Cabral (Filipe de Portugal e Espanha alterou para Deus guarde a Catholica pessoa de Vossa Magestade) que as fórmulas extremamente corteses e nem sempre sinceras já estratificadas, em que profundos são os votos de alegria e pesar e rara a emoção.

Exemplo disto: uma ata. Que é uma ata senão um relato cronológico de uma reunião? No entanto, ainda nos mantemos fiéis à tradição, à fórmula inicial de seu criador - aos tantos dias do mês tal, ano tal, na sala de reuniões, presentes os Senhores... sem o que a ata deixará de ser ata. Embora uma das recomendaçöes de lavratura seja no sentido de "sintetizar clara e precisamente as ocorrências verificadas", 78 os circunlóquios nela presentes nem sempre facilitam a clareza e concorrem para alcançá-la.

Evitamos, também, descer ao exame dos documentos jurídicos, onde não é menor a cristalização e a estereotipia das formas; além disso transbordaria os limites deste trabalho. Mas é o caso de indagar por que, em meio da evolução do saber jurídico, certas fórmulas permanecem intocadas. Isto nos faz lembrar episódio que me foi narrado, ocorrido recentemente numa aula de Direito Penal. 0 aluno, durante a exposição oral, referiu-se ao crime do réu. O professor, finda a exposição, achou-a admirável, precisa, mas, em particular, deu ao futuro criminalista este conselho: "Nunca fale nem escreva a palavra crime. Habitue-se à terminologia Jurídica: ilicito penal. Impressiona mais o público e os jurados".

Na correspondência, porém, o objetivo não é impressionar. É informar, transmitir, esclarecer, opinar. É, enfim, comunicar.

\section{IV - SUGESTÕES PRÁTICAS}

Que sugestões práticas poderiam ser apresentadas ao final deste trabalho?

Firmada a necessidade de integrar a correspondência oficial no esquema da Comunicaçăo; reconhecido o fato, pela própria dinâmica do Serviço Público, de que entraves burocráticos se localizam muitas vezes na redação dos documentos oficiais; necessário examinar tão importante setor, com observância para estes dois aspectos:

1) Revisão dos textos de redação oficial, tendo em vista a maior clareza do tema;

2) renovação estrutural dos documentos. 
No primeiro caso, o objetivo será tornar mais expressivos os textos oficiais; no segundo caso, procurar estudar a modificação estrutural dos documentos, à luz das técnicas modernas da Comunicação, sem prejuizo do conteúdo informativo ou opinativo.

No correr do desenvolvimento deste trabalho, tivemos oportunidade de mostrar o que se pode fazer em favor de uma linguagem oficial despida de atavios e circunlóquios que se manifestam nas fórmulas ditas de cortesia, na adjetivação supérflua, nas perífrases redundantes, nas metáforas, nos preciosismos, nos lugares-comuns. Enfim: em tudo o que torna o pensamento opaco e dificulta a informação, a interpretação e a opinião de quem redige.

Reconhecemos: não é tarefa que se possa fazer de uma penada, na base, digamos, de uma portaria. Naturais resistências se baseariam na afirmação de que se o texto está gramaticalmente correto, é suficiente. Ora, há textos gramaticalmente corretos e no entanto ininteligíveis. Não vamos debater este tema, que por si mesmo exige outra monografia...

Caberia, a nosso ver, ao próprio DASP iniciar amplos estudos sobre a matéria. Só através do exame objetivo dos textos oficiais é que se pode chegar a normas de redação que, sem se estratificarem em novas fórmulas, como temia Medeiros e Albuquerque, ofereçam ao redator possibilidades de criação, de renovação constante, sem quebra, evidente, das distinções específicas que caracterizam um ofício, uma ata, um memorando, uma exposição de motivos.

Tentamos salientar o tema em suas linhas gerais. Resta agora descer ao pormenor, documento por documento, se possivel na área intocável das citaçöes, dos editais, das petições, dos acórdãos jurídicos, obedecendo a um raciocínio indutivo da pesquisa, tão necessário em trabalhos dessa natureza, quanto à finalidade da própria correspondência, desde que o homem procurou fixar em símbolos o pensamento e a fala.

\section{V - REFERENNCIAS BIBLIOGRÁFICAS}

1) Daniel-Rops, Jesus no seu Tempo, Liv. Tavares Martins, Porto, Lisboa, 1956, pág. 21.

2) Ney, Joăo Luiz, Prontuário de Redaçắo Oficial, DASP - Serviço de Documentaçăo, 5. a ed., 1968, pág. 26.

3) Souza, Cauby de - Normas sobre Correspondência e Atos Oficiais, DASP - Serviço de Documentaçăo, 2.a ed., 1968.

4) Ney, Joăo Luiz - op. cit., pág. 27.

5) Souza, Cauby de - op, cit., pág. 11. 6) Beltrão, Odacir - Correspondência: Liñ. Paulo, 10.a ed., 1966, pág. 21.

7) Camara Jr., J. Mattoso - Manual de EXpressåo Oral e Escrita, 2.a J. Ozon Edito:. Rlo, 1966, pág. 71.

8) "Que eu canto o peito ilustre lusitano"! "Dou-vos também aquele ilustre Gama" (Camóes - Os Lusiadas, Canto I: 3,5 ; 12,7).

9) Beltrăo, Odacir - op. cit., pág. 30 .

10) Atribui-se a Bastos Tigre a autoria desta sextilha utilizada como texto publicitário axa "Veja Ilustre passagelna década de 40: "Veja ilustre passag tem a seu lado,/E no entretanto, acredite! Quase morreu de bronquite/Salvou-o Rhum Creosotado."

11) Rónal, Paulo - Como Aprendi o português - Outras Aventuras, Ed. do Instituto Nacional do Livro, Rio, 1956, pág. 67. 
12) Proust, Marcel - A Sombra das Raparigas em Flor, Edit. Globo, Porto Alegre, 1951, påg. 99.

13) Durant, WIII - Os Grandes Pensadores, Cia. Edit. Nacional, S. Paulo, 1946, pág. 234.

14) Lapa M. Rodrigues - Estilistica da Lingua Portuguesa, 3.a ed., Llvraria Acadêmica, Rlo, pág. 115.

15) Idem, Ibidem, pág. 105.

16) Cunha, Euclides da - Os Sertöes, Liv. Francisco Alves, 18.a, ed., Rio, 1945, pág. 114.

17) Ramos, Graciliano - s. Bernardo, 4.a ed., Liv. José Olympio Editora, Rio, 1952, pág. 94.

18) Rego, José Lins do - Doidinho, 2.a ed., Liv. José Olympio Editora, Rio, 1935, pág. 196.

19) Assis, Machado de - Obra Completa, Vol. I: Dom Casmurro, Edit. Aguillar, Rio, 1959, pág. 830 .

20) Branco, Camilo Castelo - Apud M. Rodrigues Lapa, op. cit., pág. 76.

21) Burnett, Lago - De Jornal em Jornal, Gráfica Record Editora, Rìo, 1958, pág. 133.

22) Montello, Josué - A Oratória Atual do Brasil, DASP - Serviço de Documentaçăo, 1959, pág. 5.

23) Maugham, W. Somerset - Confissores, Edit. Globo, Porto Alegre, 1951, pág. 31.

24) Escreveu Manuel Bandeira: "Năo procurem a expressão nos dicionários porque năo a encontram. Pelo dicionário, bissexto só há um ano, e é o que tem um dia a mais, - que ocorre de quatro em quatro anos. Poeta bissexto deve, pois, chamar-se aquele em cuja vida o poema acontece como o dia 29 de fevereiro do ano civil. Esquematizaçăo grosseira. Em suma, bissexto é todo poeta que só entra em estado de graça de raro em raro" (Antologia de Poetas Brasileiros Bissextos Contemporâneos, Edit. Zélio Valverde, Río, 1946). Definiçăo de Caldas Aulete, no Dicionário Contemporâneo de Língua Portuguesa: "Diz-se daquele que excepcionalmente se à dedica à literatura e em particular à poesla".

25) Maugham, W. Somerset - op. cit., pág. 28.

26) Foca; Jornalista principiante.

27) "Livro escolar Impresso em caracteres de forma manuscrita". (Dicionárlo Contemporâneo do Língua Portuguesa, de Caldas Aulete).

28) Lobato, Monteiro - Prefáclo ao romance de Marla José Dupré, Éramos Seis, Edlçăo Saraiva, S. Paulo, 14.a ed., 1968.
29) Lobato, Montelro - A Barca de Gleyre, 2. ${ }^{\circ}$ tomo, Edit Brasiliense, 1959, S. Paulo, pág. 55.

30) Mota, Mauro - O Pátio Vermelho (Crônica de uma Pensão de Estudantes), Ed. Orfeu, Rio, 1968, pág. 131.

31) Terrou, Fernand - A Informaçăo, Coleção Saber Atual, Difusăo Européia do Livro, S. Paulo, 1964, pág. 17.

32) Silva, José Afonso da - Noçőes de Técnica Legislativa in Boletim do Interior n. 0 21, ano III, Ed. da Secretaria do Interior do Governo do Estado de S. Paulo, Julho/dez. 1939.

33) Turner, Berence C. - Apud Odacir Beltrão, op. cit., pág. 19.

34) Hohemberg, John - Manual de Jornalismo, Edit. Fundo de Cultura, Rio, s/d., pág. 33.

35) Correio Braziliense, 10.6.1970.

36) Beltrăo, Odacir - op. cit., pág. 77.

37) Souza, Cauby de - op. cit., pág. 73.

38) Diário do Congresso Nacional, Seçăo I, 31.7.70, pág. 3.533.

39) Beltrăo, Odacir - op. cit., pág. 17.

40) Mercanti, Luis - Apud Odacir Beltrăo, op. cit. pág. 26.

41) Apud Odacir Beltrăo, op. cit., pág. ' 26.'

42) Lafuerza, N.D. - Apud Odacir Beltrăo, op. cit., pág. 26.

43) Montaigne, Michel de - Ensaios, Livro III, Cap. 13. Editora Globo, Porto Alegre, 1961, págs. $322 / 323$.

44) Medeiros e Albuquerque - Quando eu Era Vivo, 2.a ed., Editora Globo, Porto Alegre, 1945, págs. 91-92.

45) Guerra, José Augusto - O Mito da Impessoalidade na Redaçăo Oficial, in Revista do Serviço Públlico, Vol. 105, n.० 1, Jan./abril, 1970.

46) Bandeira, Manuel - Poesia e Prosa, Vol. I (Poesia), Ed. Aguillar, Rio, 1958, págs. 537-538.

47) Matos, Gregório de - Obras Completas, Vol. II, Editora Janaina, Salvador, 1969, pág. 416.

48) Carneiro, Glauco o Fontes, Lourival A Face Final de Vargas (Os Bilhetes de Getúlio), Edições O Cruzeiro, Rio, 1966, pág. 140.

49) Idem, ibidem, pág. 129.

50) Barbosa, Ruy - Apud Joăo Luis Ney, op. cit., pág. 171. 
51) Souza, Cauby de - op. cit. págs. 9-10.

52) Freyre, Gilberto - Soclologia, V. II, 2.a ed., Liv. José Olympio Edit., Rio, 1957, pág. 36.

53) Apud Arthur Ramos - Introduçăo à Palcologia Social, 2.a ed., Casa do Estudante do Brasil, Rlo, 1952, pág. 126.

54) Idèm, Ibldem, pág. 124.

55) Expressão preferida por Gilberto Freyre: op. cit., pág. 359.

56) Guedes, Joăo Alfredo Libânio e Ribeiro, Joaquim - História Administrativa do Brasil, Vol. III, DASP - Serviço de Documentaçăo, 1966, págs. 275-278.

57) Penteado, J. R. Whitaker - A Técnica da Comunicaçăo Humana, Liv. Pioneira Editora, São Paulo, 1964.

58) Balzac. Honoré de - Os Funcionários in A comédla Humana, vol. XI, Edit. Globo, Porto Alegre, 1968, pág. 256.

59) Apud Humberto de Campos, Brasil Aned6tíco, Edit. Mérito, S. Paulo, 1960, pág. 29.

60) Beltrăo, Odacir - op. cit., pág. 43.

61) Oliveira, Franklin de - 0 Espirlto Inquebrantável de Graciliano Ramos in Revista do Diner's, n.o năo Identificado, págs. 39-41.

62) Rego, José Lins do - Gordos e Magros Ed. Casa do Estudante do Brasil, Rio, 1942, pág. 4.

63) Apud Luiz Amaral - Jornalismo, Matérla de Primelra Página, Ed. Tempo Brasileiro, Rio, 1967, pág. 32 .
64) Magalhães Jr., R. - Machado de Assis Desconhecido, 3.a ed., Edit. Civilizaçẵo Brasileira, Rio, 1957, pág. 180.

65) Idem, ibidem, pâg. 192-193.

66) Idem, ibidem, pág. 199.

67) Guedes, Joăo Alfredo Libanio e Ribeiro, Joaquim - op. cit., pág. 272.

68) Vocabulário da Carta de Pero Vaz de Caminha (Introduçăo do Prof. Silvio Batista Pereira), Ed. do Instituto Nacional do Livro, Rio, 1964, págs. XVIII @ XIX.

69) Cortesăo, Jayme - Cabral e as Origens do Brasil, Edição do Ministério das Relaçőes Exteriores, Río, 1944, pág. 141.

70) Idem, ibidem, pág. 167.

71) Tapajós, Vicente - História Administrativa do Brasil, Vol. II, DASP - Serviço de Documentaçăo, 1956, pág. 167.

72) Idem, Ibidem, pág. 193.

73) Idem, ibidem, pág. 195.

74) Garcia, Othon M. - Comunicaçăo em Prosa Moderna, Fundaçăo Getúlio Vargas, Rio, 1967, pág. 201.

75) Meyer, Augusto - Preto \& Branco, Instituto Nacional do Livro, 1956, pág. 222

76) Chaffurin, Louis - Le Parfait Secrétaire, Librairie Larousse, Paris, 1969, págs. 7-8.

77) Marshall MacLuhan - Os Melos do Comunleaçăo como Extensőes do Homem, Edit. Cultrix, S. Paulo, 1969.

78) Beitrẵo, Odacir - op. cit., pág. 71. 